\title{
Revisão de Mitracarpus (Rubiaceae - Spermacoceae) para o Brasil ${ }^{1}$ \\ Revision of Mitracarpus (Rubiaceae -Spermacoceae) from Brazil
}

\author{
Elnatan Bezerra de Souza ${ }^{2}$, Elsa Leonor Cabral ${ }^{3}$ \& \\ Daniela Cristina Zappi ${ }^{4}$
}

\begin{abstract}
Resumo
O presente trabalho consiste da revisão de Mitracarpus para o Brasil, com base em observações de campo e estudo de espécimes de herbário. Mitracarpus é um gênero neotropical, distribuindo-se desde o sul dos Estados Unidos até o centro da Argentina, com uma espécie invasora ocorrendo nos Paleotrópicos. O gênero apresenta três centros de diversidade de espécies: o México, o Caribe e o Brasil. Vinte e quatro espécies são reconhecidas, das quais seis novas para a ciência: Mitracarpus albomarginatus, M. buiquensis, M. diversifolius, M. eitenii, M. nitidus e M. robustus. Chave de identificação, nomenclatura, descrições, ilustrações e notas sobre o estado de conservação das espécies são apresentados.

Palavras-chave: conservação, neotrópico, Rubioideae, taxonomia.
\end{abstract}

\begin{abstract}
This paper presents the revision of Mitracarpus from Brazil. The study is based on field observations and study of herbarium specimens. Mitracarpus is a neotropical genus, distributed from the southern United States to central Argentina, with one invasive species occurring in the Old World. The genus presents three centres of diversity: Mexico, the Caribbean region and Brazil. Twenty four species are accepted, of which six are new to science: Mitracarpus albomarginatus, M. buiquensis, M. diversifolius, M. eitenii, M. nitidus and M. robustus. A key to identify the species, updating of the names and their typification, synonymy, descriptions, illustrations are provided, together with data on their conservation status.
\end{abstract}

Key words: conservation, Neotropics, Rubioideae, taxonomy.

\section{Introdução}

Mitracarpus Zucc. ex Schult. \& Schult. f. (Rubiaceae) é um dos 19 gêneros circunscritos na tribo Spermacoceae sensu stricto. O gênero pode ser morfologicamente diagnosticado pelo cálice formado por quatro lobos, dois maiores e dois menores, pelo fruto capsular com deiscência transversal e pela forma do encaixe (depressão) ventral das sementes. Análises moleculares baseadas em dados de rps 16 intron e ITS suportaram o seu monofiletismo, embora sua posição no clado das Spermacoceae s.s. ainda seja incerta (Dessein 2003). Em um estudo preliminar dos frutos e sementes de gêneros representativos da tribo Spermacoceae, Mitracarpus foi considerado um gênero com sementes únicas, caráter que poderia ser utilizado para considerá-lo como uma subtribo distinta (Terrell \& Wunderlin 2002).

Após o tratamento taxonômico proposto por Schumann (1888), as contribuições à taxonomia de Mitracarpus consistiram de redescrições em estudos florísticos e da publicação de novas espécies, especialmente para o Caribe e o México (Urban 1903, 1908, 1913, 1928; Borhidi \&Lozada 2007). A publicação de listagens em floras regionais e a descrição de novas espécies evidenciaram, contudo, a necessidade de

\footnotetext{
Parte da tese de Doutorado do primeiro autor desenvolvida no Programa de Pós-Graduação em Botânica (PPGBot) da Universidade Estadual de Feira de Santana (UEFS). ${ }^{2}$ Universidade Estadual Vale do Acaraú, Coordenação de Biologia, Avenida da Universidade, 850 - Betânia, 62040-370, Sobral, CE, Brasil. elbezsouza@yahoo.com.br ${ }^{3}$ Facultad de Ciencias Exactas, Físicas y Naturales y Agrimensura (UNNE), Instituto de Botánica del Nordeste, Corrientes, Argentina.

${ }^{4}$ Herbarium, Royal Botanic Gardens, Kew, TW93AA, UK.
} 
uma revisão nomenclatural e de uma melhor definição das suas espécies. Em adição, está o fato de que o único tratamento existente é o de Schumann (1888) para a Flora brasiliensis, onde ele descreveu 10 espécies e propôs duas secções para Mitracarpus.

Devido à similaridade morfológica entre amostras herborizadas, espécies deste gênero são comumente confundidas com representantes de grupos afins, tais como Borreria G. Mey., Diodella Small, Diodia L., Richardia L., Spermacoce L. e Staelia Cham. \& Schltdl. Em conseqüência, muitas coleções de herbário apresentam identificações imprecisas quanto à identidade genérica, ou são determinadas com binômios incorretos por falta de uma revisão nomenclatural, o que tem causado muita confusão nas listagens florísticas.

Com base nessas considerações, realizou-se a revisão das espécies do centro de diversidade brasileiro, que abrange a maior parte das espécies sulamericanas de Mitracarpus. Este tratamento é o primeiro passo para a revisão completa do gênero e consiste de aspectos morfológicos, taxonômicos, distribuição geográfica e da categoria de conservação das espécies.

\section{Material e Métodos}

O presente estudo foi baseado na análise de cerca de 1.269 espécimes (Apêndice) provenientes de coletas e de herbários do Brasil e do exterior, citados no material examindado, acrônimos citados conforme Holmgren et al. (1990): ALCB, BHCB, BM, BR, CEN, CEPEC, CTES, CVRD, EAC, ESA, FLOR, G, HAS, HBR, HRB, HUEFS, IAN, IBGE, ICN, INPA, IPA, JPB, HUVA, K, L, MBM, MEXU, MG, MO, NY, P, PACA, PEUFR, R, RB, SI, SP, SPF, U, UB, UEC, VIC, W.

As citações das obras príncipes estão de acordo com o Taxonomic Literature (Stafleu \& Cowan 1976-1986). Os critérios para tipificação estão fundamentados no Código Internacional de Nomenclatura Botânica (McNeill et al. 2006).

As espécies foram analisadas, para efeito de avaliação do seu estado de conservação, de acordo com as categorias e critérios da IUCN (2001), fornecendo subsídios para a priorização daquelas que dever ser protegidas através de estratégias de conservação.

O estudo morfológico foi realizado sob microscópio estereoscópio e as mediadas tomadas com auxilio de um escalímetro. As medidas da corola foram tomadas considerando-se o comprimento desde a base do tubo até a extremidade dos lobos; as dos lobos do cálice foram tomadas considerando o comprimento das projeções, sem incluir o tubo.
Os dados da distribuição geográfica das espécies foram obtidos a partir das etiquetas das exsicatas e da literatura especializada (Schumann 1888; Bacigalupo 1974, 1993, 1996; Porto et al. 1977; Steyermark 1972, 1974; Andersson 1992; Delprete et al.2005).

\section{Resultados e Discussão}

\section{Tratamento taxonômico}

Mitracarpus Zucc. ex Schult. \& Schult. f. Mant. 3: 210. 1827. Tipo: M. scaber Zucc. ex Schult. \& Schult. f. [M. hirtus (L.) DC.].

Spermacoce Jacq. ('non L.'), Icon. Plant. Rar.: tab. 308. 1788. Staurospermum Thonn., Beskr. Guin. Pl.: 73. 1827. Tipo: S. verticillatum Schumach. \& Thonn. Schizangium Bartl. ex DC., Prodr. 4: 571. 1830. Tipo: S. durum Bartl. ex DC.

Ervas anuais ou perenes, ou subarbustos eretos, ascendentes, prostrados ou decumbentes. Caules tetrágonos, subtetrágonos ou cilíndricos, alados ou não, solitários ou profusamente ramificados. Estípulas fundidas à base das folhas numa bainha basal, fimbriadas, encimadas por setas lineares ou linear-lanceoladas, geralmente com um coléter apical. Folhas monomórficas, ou raramente dimórficas (em Mitracarpus diversifolius), opostas ou pseudoverticiladas pela presença de braquiblastos nas axilas, (sub)sésseis ou pseudopecioladas, lâminas foliares estreitas, lineares, elípticas, lanceoladas ou ovadas, herbáceas, cartáceas, semisuculentas, ou (sub)coriáceas; nervuras secundárias impressas ou completamente submersas na lâmina. Ramos florais com glomérulos terminais e/ou axilares, pauci ou densifloros, raramente com fascículos axilares unilaterais (M. diversifolius), subtendidos por 2-8 brácteas foliáceas. Flores tetrâmeras, sésseis ou subsésseis, hermafroditas, homógamas, protândricas; hipanto turbinado, obcônico a subgloboso. Cálice persistente, com quatro lobos, dois maiores e dois menores, raramente com lobos subiguais. Corola hipocrateriforme ou (sub)infundibuliforme, alva; tubo glabro ou pubérulo externamente, dotado de anel ou faixa de tricomas moniliformes internamente; lobos 4, valvados no botão. Estames 4, subsésseis, inseridos na fauce da corola; anteras oblongas a subelípticas, dorsifixas, subinclusas ou raramente inclusas. Estilete filiforme, bífido; ovário 2-locular, cada lóculo com um óvulo fixado ao septo. Fruto capsular com deiscência transversal, abrindo-se em duas partes: a porção superior em forma de "mitra", coroada pelos lobos do cálice persistentes, a porção inferior formada pela base dos carpelos e a parte basal do septo sobre o pedúnculo. Sementes 
oblongóides, obovóides a globosas, dorsalmente sem depressões ou portando depressão cruciforme, raramente com depressões semicirculares apicais, com exotesta lisa, reticulada, retículo-foveolada ou papilada, ventralmente com encaixe (depressão) em forma de "X", "Y-invertido" ou aproximadamente retangular ou quadrangular profundamente impresso e geralmente coberto por excrescência granular; prolongamentos do encaixe ventral evidentes ou não nos ângulos da face dorsal.

Mitracarpus é um táxon neotropical, distribuído desde o sul dos Estados Unidos até o centro da Argentina. Sua etimologia refere-se à estrutura do fruto, cuja porção apical, dotada de duas projeções superiores, se assemelha a uma "mitra" (o chapéu do bispo). O gênero apresenta três centros de diversidade: no México, no Caribe e no Brasil. O número de espécies está em torno de 50, com 13 registradas para o México (Borhidi \& Lozada 2007), 13 para Cuba(Liogier 1963)e 10 para Espanhola e Porto Rico (Liogier 1995, 1997). Mitracarpus hirtus (L.) DC. é a espécie mais amplamente distribuída ocorrendo de forma subespontânea na África, Ásia e Oceania (Verdcourt 1975; Nicolson 1977; Fosberg et al. 1993; Dessein 2003). No Brasil, são aqui reconhecidas 24 espécies (Anexo), das quais seis são novas para a ciência.

\section{Chave para identificação das espécies de Mitracarpus no Brasil}

1. Folhas dimórficas dispostas aos pares; ramo floral com fascículos axilares e unilaterais

6. M. diversifolius

1'. Folhas monomórficas; ramo floral com glomérulos terminais e/ou axilares, não unilaterais

2. Tubo da corola menor do que os maiores lobos do cálice.

3. Folhas pseudoverticiladas pela presença de braquiblastos nas axilas das folhas basais.

4. Erva de pequeno porte, com raízes delgadas; folhas cartáceo-rígidas

15. M. microspermus

4'. Subarbusto basalmente lenhoso, com raízes espessas, torcidas e estriadas; folhas semisuculentas

2. M. anthospermoides

3. Folhas opostas, sem a presença de braquiblastos nas axilas das folhas basais.

5. Caules alados na base; lobos menores do cálice filiformes; cápsulas glabras no ápice..

4. M. brasiliensis

5'. Caules sem alas; lobos menores do cálice estreito-triangulares; cápsulas pilosas ou pubérulas no ápice.

6. Ervas com caules de $15-70 \mathrm{~cm}$ compr.; tubo da corola pubérulo-papiloso externamente

6'. Ervas com caules de $2-10 \mathrm{~cm}$ compr.; tubo da corola glabro externamente.

7. Plantas prostradas; folhas pubescentes, margens foliares espessadas; corola 2-2,4 mm compr. 9. M. eritrichoides

7'. Plantas eretas ou decumbentes; folhas híspidas, margens foliares não espessadas; corola $1-1,2 \mathrm{~mm}$ compr.

17. M. parvulus

2'. Tubo da corola com o mesmo comprimento ou maior do que os maiores lobos do cálice.

8. Folhas coriáceo-rígidas, base foliar cordada, subcordada, subauriculada, estreito-atenuada ou truncada.

9. Margens foliares alvo-ciliadas; sementes com exotesta reticulada ..... 1. M. albomarginatus

9'. Margens foliares não alvo-ciliadas; sementes com exotesta papilada.

10. Erva decumbente ou prostrada; margens foliares sem espessamento

18. M. pusillus

10'. Erva ereta; margens foliares espessadas.

11. Folhas híspidas; estames com anteras subinclusas no tubo da corola

19. M. recurvatus

11'. Folhas glabras, ou pubescentes ao longo da nervura principal; estames totalmente inclusos no tubo da corola 24. M. steyermarkii

8'. Folhas herbáceas, cartáceas ou semisuculentas, base foliar atenuada, cuneada, aguda ou oblíqua.

12. Sementes com encaixe ventral quadrangular ou retangular. 
13. Subarbusto ereto ou ascendente; caule, bainha estipular e lâminas foliares glabros; corola glabra externamente

12. M. lhotzkyanus

13'. Subarbusto decumbente; caule, bainha estipular e lâminas foliares pilosos; corola pubérulo-papilosa externamente 14. M. megapotamicus

12'. Sementes com outras formas de encaixe ventral.

14. Sementes com encaixe ventral em forma de "Y-invertido".

15. Ervas cespitosas, prostradas ou decumbentes; folhas semisuculentas; margens foliares glabras, espessadas

15'. Ervas ou subarbustos eretos ou ascendentes; folhas cartáceas; margens foliares escabras, não espessadas

22. M. salzmannianus

14'. Sementes com encaixe ventral em forma de " $X$ ".

16. Sementes com depressão cruciforme dorsal.

17. Folhas opostas; tubo da corola glabro externamente.

3. M. baturitensis

17’. Folhas pseudoverticiladas; tubo corola pubérulo ou pubérulo-papiloso na porção superior externa.

18. Folhas semisuculentas, 0,5-2 mm larg.; bainha estipular com 1-3 setas

20. M. rigidifolius

18'. Folhas cartáceas ou subcoriáceas, 2-20 mm larg.; bainha estipular com 3-12 setas.

19. Bainha estipular subcoriácea, com 3 setas; lobos da corola papilados internamente

23. M. schininianus

19'. Bainha estipular membranácea, com 4-12 setas; lobos da corola glabros internamente.

20. Erva 10-20 cm alt.; caules sem alas; folhas estreito-elípticas ou elípticas

5. M. buiquensis

20'. Erva ou subarbusto 30-200 cm alt.; caules alados; folhas lanceoladas ou linear-lanceoladas, raramente lineares.

10. M. frigidus

16'. Sementes sem depressão cruciforme dorsal.

21. Sementes com depressões semicirculares dorsais.

13. M. longicalyx

21'. Sementes sem depressões semicirculares dorsais.

22. Subarbusto 70-200 cm alt.; caules alados; glomérulo terminal com 2 brácteas .......

21. M. robustus

22'. Erva ou subarbusto $7-50 \mathrm{~cm}$ alt.; caules sem alas; glomérulo terminal com 4 brácteas.

23. Folhas e caules pilosos; lobos maiores do cálice 3-4 mm compr.; corola pubérula externamente

8. M. eitenii

23'. Folhas e caules glabros; lobos maiores do cálice 2-2,5 mm compr.; corola glabra externamente

16. M. nitidus

1. Mitracarpus albomarginatus E.B. Souza, $s p$. nov. Tipo: BRASIL. BAHIA: Casa Nova, Fazenda Santarém, Sítio Morrinho, 09³6'38'S, 41¹9'43”W, 410 m, 10.X.2004, fl. e fr., L.P. Queiroz et al. 9648 (holótipo HUEFS).

Fig. 1 a-h

Haec species M. steyermarkii similis, sed foliis ovatis ad suborbicularibus (nec lanceolatis ad linearlanceolatis), corolla 4-5 mm longa dense puberula (nec 5-7 mm longa extus glabra), staminibus subinclusis (nec omnino in corollae tubis inclusis) et seminibus reticulatis (nec papillatis) differt.

Erva decumbente ou prostrada. Caules 6-21 cm compr., tetrágonos, híspido-vilosos. Bainha estipular 1-2 mm compr., híspida, com 5-7 setas, 2-3 mm compr., ciliadas. Folhas opostas, sem braquiblastos nas axilas, sésseis; lâminas 6-22×4-13 mm, ovadas a suborbiculares, cuspidadas, agudo-mucronadas ou apiculadas no ápice, subcordadas ou subauriculadas na base, cartáceo-rígidas, onduladas, espessadas, alvo-ciliadas nas margens, com tricomas maiores nas porções basais, pubérulas em ambas as faces; nervuras secundárias inconspícuas. Ramos florais com 1-(2) glomérulos terminais; glomérulos 8-16 mm diâm., globosos, densifloros, subtendidos por 2-8 brácteas foliáceas. Flores subsésseis, pedicelos ca. 0,5-1 mm compr. Hipanto obcônico, glabro. Cálice com pares de lobos subiguais, os maiores 2,5-3,5 mm compr., os menores 2-3 mm compr., lanceolado- 


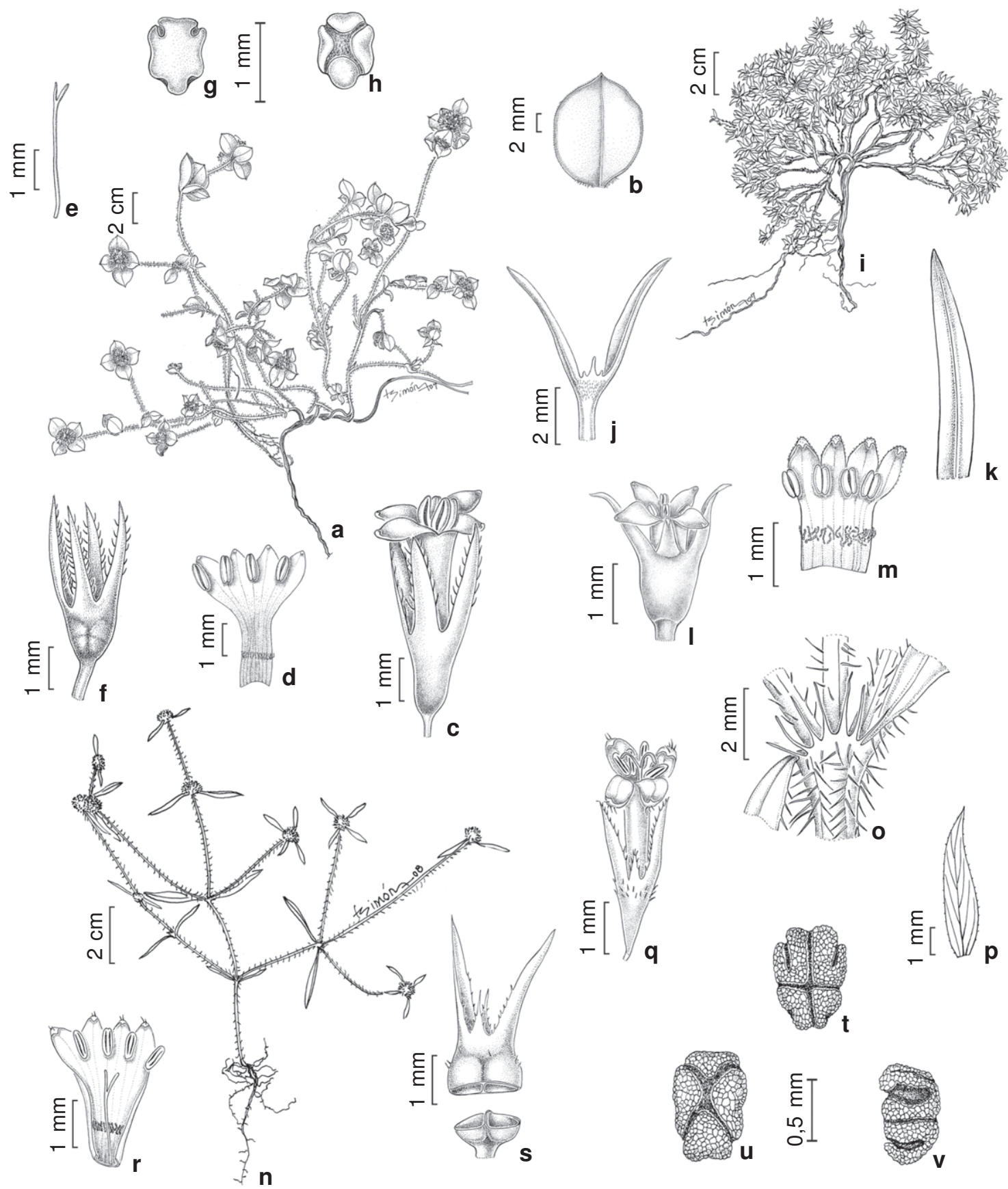

Figura 1-a-h. Mitracarpus albomarginatus - a. hábito; b. folha; c. flor; d. corola aberta; e. estilete; f. cápsula imatura; g. semente, face dorsal; h. semente, face ventral. i-m. M. Anthospermoides -i. hábito; j. bainha estipular; k. folha; 1 . flor; m. corola aberta. n-v. M. baturitensis - n. hábito; o. bainha estipular; p. folha; q. flor; r. corola aberta; s. cápsula aberta; t-v. semente; t. face dorsal; u. face ventral; v. face lateral. (a-h Queiroz et al. 9648; i Guedes 1241; j-m Félix 2647; n-s Miranda et al. 811; t-v Vidal 886).

Figure 1 - a-h. Mitracarpus albomarginatus - a. habit; b. leaf; c. flower; d. open corolla; e. style; f. young fruit; g. seed, dorsal view; h. seed, ventral view. i-m. M. anthospermoides - i. habit; j. stipular sheath; k. leaf; 1. flower; m. open corolla. n-v. M. baturitensis n. habit; o. stipular sheath; p. leaf; q. flower; r. open corolla; s. open fruit; t-v. seed; t. dorsal view; u. ventral view; v. lateral view. (a-h Queiroz et al. 9648; i Guedes 1241; j-m Félix 2647; n-s Miranda et al. 811; t-v Vidal 886). 
acuminados, fortemente ciliados nas margens. Corola 4-5 mm compr., hipocrateriforme; tubo 2,5-3 mm compr., densamente pubérulo na metade superior externa, com anel de tricomas moniliformes na metade inferior interna; lobos 1-1,5 mm compr., ovados, externamente papilados no ápice, pubérulos na face interna. Estames sésseis; anteras ca. 0,8-1×0,3-0,4 mm, elipsóides, subinclusas. Estilete 4-4,5 mm compr.; ramos estigmáticos $1 \mathrm{~mm}$ compr., filiformes. Cápsulas 1,2-1,5 × 0,8-1 mm, turbinadas, glabras. Sementes $0,6-1 \times 0,5-0,6 \mathrm{~mm}$, oblongóides ou obovóides, castanho-claras a castanho-escuras; face dorsal com depressão cruciforme suavemente impressa, exotesta reticulada; face ventral com encaixe em forma de " $X$ ".

Material examinado: BRASIL. BAHIA: Juazeiro, 26.II.1962, fl., A.L. Costa 1041 (ALCB); Casa Nova, 9¹6'49''S, 41'22'7'W, 18.IV.2004, fl. e fr., T.S. Nunes et al. 1105 (HUEFS). PERNAMBUCO: Orocó, 9³8'12"S, $39^{\circ} 42^{\prime} 50^{\prime \prime}$ W, 27.IV.2001, fl. e fr., R.M. Harley et al. 54317 (HUEFS).

Mitracarpus albomarginatus assemelha-se a M. steyermarkii E.L. Cabral \& Bacigalupo (Cabral $\&$ Bacigalupo 1997), da qual se distingue pela corola densamente pubérula externamente (vs. glabra), pelos estames (sub)inclusos no tubo da corola ( $v s$. complemente inclusos) e sementes reticuladas (vs. papiladas). Mitracarpus albomarginatus ocorre em áreas ao longo do Rio São Francisco, entre os municípios de Juazeiro e Casa Nova, na Bahia, e Orocó, em Pernambuco. A espécie parece ser endêmica do Sertão do Submédio São Francisco e Sudoeste de Pernambuco, uma das áreas prioritárias para conservação da flora da Caatinga (Velloso et al. 2002). A espécie é considerada ameaçada [EN B2ab (ii, iii, iv)] por apresentar distribuição restrita, às margens do Rio São Francisco, onde grandes represas e subseqüentes empreendimentos agrícolas têm sido instalados, eliminando parte de suas populações. Nenhuma das populações conhecidas encontra-se protegida em unidade de conservação.

2. Mitracarpus anthospermoides K. Schum., Martius, Eichler \& Urban, Fl. Bras. 6(6): 86. 1888. Tipo: BRASIL. BAHIA: fl. e fr., J. Blanchet 1867 (holótipo B†; lectótipo BR!, aqui designado; isolectótipo BM!, G!, K!, W!).

Fig. $1 \mathrm{i}-\mathrm{m}$

Subarbusto prostrado, decumbente ou, mais raramente, ascendente, geralmente formando touceiras, basalmente lenhoso, com raízes espessas, torcidas, estriadas. Caules (5-)10-30 cm compr., radialmente dispostos, cilíndricos na base, tetrágonos nas porções apicais, levemente pubérulos ou glabrescentes, basalmente marcados por cicatrizes de bainhas ressequidas. Bainha estipular, ca. 0,5 mm compr., glabra, com 1-3 setas, estreito-triangulares, 0,6-1,2 $\mathrm{mm}$ compr. Folhas pseudoverticiladas pela presença de braquiblastos axilares, sésseis; lâminas 3-7×0,5-1 mm, lineares a linear-lanceoladas, agudas no ápice, atenuadas na base, semisuculentas, glabras nas margens e nas faces; nervuras secundárias inconspícuas. Ramos florais emergentes com 1-5 fascículos ou glomérulos terminais paucifloros; glomérulos 4-6 mm diâm., subtendidos por 2-8 brácteas foliáceas. Flores subsésseis, pedicelos ca. 0,5-1 mm compr. Hipanto turbinado, glabro. Cálice com pares de lobos desiguais, os maiores 1,5-2 mm compr., lanceolados, os menores ca. 0,5 mm compr., triangulares. Corola 1,5-2,5 mm compr., hipocrateriforme; tubo ca. $1 \mathrm{~mm}$ compr., externamente glabro, com anel de tricomas na metade inferior interna; lobos ca. $0,5 \times 0,4 \mathrm{~mm}$, ovados, glabros. Estames sésseis; anteras ca. 0,5 × 0,3 mm, oblongas, subinclusas. Estilete 1-1,5 mm compr.; ramos estigmáticos ca. 0,5 mm compr. Cápsulas 1,2-1,5 mm compr., obcônicas, glabras. Sementes 0,5-0,8 × 0,5-0,6 mm, oblongóides ou globosas, castanhas a castanho-escuras; face dorsal sem depressão cruciforme, exotesta fovéolo-reticulada; face ventral com encaixe em forma de " $X$ ", esparsamente coberto por excrescência granular. Material selecionado: BRASIL. BAHIA: Camaçari, Dto. Arembepe, 10.II.1990, fl., L.P. Felix 2647 (K). Entre Rios, 27.V.1981, fl. e fr., B.M. Boom \& S.A. Mori 983 (CEPEC). Lauro de Freitas, Praia de Ipitanga, 14.I.1987, fl. e fr., M.L. Guedes 1241 (ALCB). Mata de São João, 12³1'S, $38^{\circ} 17^{\prime}$ W, 3.II.2001, fl. e fr., M.L. Guedes et al. 8207 (ALCB). Salvador, Dunas do Abaeté, $12^{\circ} 58^{\prime} \mathrm{S}, 38^{\circ} 30^{\prime} \mathrm{W}$, 12.IX.1999, fl. e fr., A.T. Rodarte et al. 33 (ALCB).

Mitracarpus anthospermoides caracteriza-se pelas folhas semisuculentas, lineares ou linearlanceoladas, glabras, corola externamente glabra, menor dos que os maiores lobos do cálice e sementes com exotesta fovéolo-reticulada. Esta espécie relacionase com $M$. rigidifolius, com a qual compartilha folhas semisuculentas, lineares e sementes com exotesta fovéolo-reticulada. A análise dos materiais do acervo do herbário BR permitiu encontrar um exemplar de Blanchet 1867 em bom estado de conservação e apresentando flores e frutos, o que justificou sua escolha como lectótipo de $M$. anthospermoides. Espécie restrita ao Brasil, no litoral do estado da Bahia. Ocorre nas restingas herbáceoarbustivas entre os municípios de Salvador e Camaçari, formando pequenas populações com indivíduos esparsos, sobre solos arenosos profundos. Quanto a seu status de conservação, a espécie é considerada 
vulnerável [VU A3c]. A área de ocorrência desta espécie vem sendo progressivamente fragmentada pelos empreendimentos imobiliários, turísticos e/ou atividades industriais. Nenhuma de suas populações está localizada em unidade de conservação.

3. Mitracarpus baturitensis Sucre, Rodriguésia 26(38): 255. 1971. Tipo: BRASIL. CEARÁ: fl. e fr., $A$. Löfgren 898 (holótipo RB!).

Fig. $1 \mathrm{n}-\mathrm{v}$

Erva ereta (13-)35-70 cm alt. Caules tetrágonos a subtetrágonos, com ramos opostos, glabros ou levemente pilosos sob a bainha estipular, ou densamente híspidos nas margens, vilosos nas faces. Bainha estipular 1-2 mm compr., brancopilosa, com 5-7 setas, 1-1,5 compr., esparsamente ciliadas. Folhas opostas, sem braquiblastos nas axilas, sésseis; lâminas 9-45×2-10 mm, estreitoelípticas, agudas no ápice, agudas na base, herbáceas, com margens revolutas, ciliadas; face superior glabra ou escabra, ou glabra sobre a superfície e pubescente sobre as nervuras; face inferior glabra, com nervura principal proeminente, pubescente; nervuras secundárias 2-3 pares, inconspícuas. Ramos florais com $1-3(-5)$ glomérulos axilares e terminais; glomérulos 5-7 mm diâm., subtendidos por 2-4 brácteas foliáceas. Flores subsésseis, pedicelos ca. 0,5-1 mm compr. Hipanto ca. 0,5 mm compr., obovado, glabro. Cálice com pares de lobos desiguais, os maiores 1-1,2 mm compr., ovados ou lanceolados, com uma nervura central parda, densamente ciliados, os menores 0,6 $0,8 \mathrm{~mm}$ compr., lanceolados, ciliados. Corola $2-3 \mathrm{~mm}$ compr., hipocateriforme; tubo de 1,2-2 mm compr., glabro externamente, com anel de tricomas moniliformes na metade interna; lobos ca. 0,6$0,8 \mathrm{~mm}$ compr., ovados. Estames sésseis; anteras ca. $0,6 \times 0,3 \mathrm{~mm}$ compr., oblongas, subinclusas. Estilete 1,8-2,5 mm compr.; ramos estigmáticos ca. $0,5 \mathrm{~mm}$ compr. Cápsulas globosas, 1-1,5 mm compr., glabras ou pilosas no ápice, pedúnculo $0,3-0,5 \mathrm{~mm}$ compr. Sementes ca. 0,6-1 $\times 0,5 \mathrm{~mm}$, oblongóides ou globosas, castanhas; face dorsal com depressão cruciforme impressa, exotesta fovéolo-reticulada; face ventral com encaixe em forma de " $X$ ".

Material selecionado: BRASIL. BAHIA: Caitité, $14^{\circ} 07^{\prime}$ 'S, 42³0'W, 13.IV.1980, fl. e fr., R.M. Harley et al. 21325 (CEPEC, K). Itaberaba, Morro Itibiraba, 12³0'04”'S, 4004'59”'W, 23.X.2005, fl. e fr., E. Melo et al. 4139 (HUEFS). Paulo Afonso, Raso da Catarina, 09³9'12'S, 38²' '14'W, 10.VIII.2005, fl. e fr., E.B. Miranda et al. 811 (HUEFS). CEARÁ: Quixeramobim, Serrote Serra D'água, 27.VIII.1992, fl. e fr., E.B. Souza s.n. (EAC 20138). Sobral, Serra do Rosário, Sítio São Miguel, 0341'55”S, 40³0'61”W,
22.VI.2002, fl. e fr., E.B. Souza 708 (HUVA, HUEFS). S. loc., Serra de Baturité, Sítio B. Inácio de Azevedo, V.1938, fl., J. Eugênio 1120 (RB). DISTRITO FEDERAL: Brasília, Campus da UnB, $15^{\circ} 45^{\prime} \mathrm{S}, 47^{\circ} 52^{\prime} \mathrm{W}, 5 . \mathrm{V} .1981$, fl., F.C. Silva et al. 428 (IBGE, UB). Planaltina, CPAC, $15^{\circ} 37^{\prime} \mathrm{S}$, 4742’ W, 15.IV.2005, fl., E.B. Souza et al. 1189, 1190 (HUEFS). GOIÁS: Cristalina, 7.III.1966, fl. e fr., H.S. Irwin et al. 13753 (MBM). Pirenópolis, 1549'00'S, 4853'00”'W, 24.IV.1994, fl., S. Splett 202 (UB). MATO GROSSO: Nova Xavantina, $14^{\circ} 49^{\prime} 46^{\prime \prime}$, 52 $2^{\circ} 17^{\prime} 49^{\prime \prime} \mathrm{W}$, 17.IV.2005, fl., E.B. Souza et al. 1226 (HUEFS). Santo Antônio do Leverger, 15'43'52'S, 5605'24"'W, 24.IV.2005, fl. e fr., E.B. Souza et al. 1319, 1321, 1323 (HUEFS). PARAÍBA: Esperança, 14.IX.1958, fl. e fr., J.C. Moraes 1900 (JPB, U). Pocinhos, 19.V.1988, fl. e fr., L.P. Félix \& M.F. Silva 1096 (JPB, K). PERNAMBUCO. Buíque, Serra do Catimbau, $08^{\circ} 37^{\prime} \mathrm{S}$, 37010'W, 16.IX.1994, fl. e fr., M.F. Sales et al. 370 (K). Petrolândia, IV.1954, fl. e fr., J. Vidal 829, 886 (R). PIAUÍ: Campo Maior, 15.IV.1992, fl. e fr., M.S. Bona 63 (EAC).

Mitracarpus baturitensis caracteriza-se pelos caules de ramificação oposta, pela corola glabra externamente e pelas sementes com depressão cruciforme dorsal. Muitos exemplares de herbário foram erroneamente identificados como $M$. scabrellus (= M. salzmannianus), provavelmente devido aos caracteres florais e pela folhas estreito-elípticas e escabras. Contudo, estas entidades são distintas: $M$. baturitensis possui folhas opostas (vs. folhas pseudoverticiladas em $M$. salzmannianus) e sementes com depressão cruciforme dorsal e encaixe ventral em forma de "X" ( $v s$. sementes sem depressão cruciforme dorsal e encaixe ventral em forma de "Y-invertido"). Mitracarpus baturitensis é restrito ao Brasil, sendo referido para o Distrito Federal e para os estados do Piauí, Ceará, Paraíba, Pernambuco, Bahia, Goiás e Mato Grosso. É uma espécie heliófita, encontrada entre 40 e $1.000 \mathrm{~m}$ de altitude, preferencialmente sobre solos rochosos, lateríticos, ou sobre inselbergs e afloramentos rochosos no Bioma Caatinga e no Cerrado. Quanto a seu status de conservação, a espécie é considerada como não ameaçada [NE].

4. Mitracarpus brasiliensis M.L. Porto \& Waechter, Fl. Ilustr. Rio Grande do Sul. 12: 90. 1977. Tipo: BRASIL. RIO GRANDE DO SUL: São Francisco de Paula, 4.V.1975, fl. e fr., J.L. Waechter 56 (holótipo ICN!).

Fig. 2 a-g

Erva ereta ou ascendente, $30-45 \mathrm{~cm}$ alt. Caules tetrágonos, alados, pubescentes nas margens. Bainha estipular ca. $2 \mathrm{~mm}$ compr., glabra ou com pubescência esparsa, com 7-9 setas, 1,5-2 mm. Folhas opostas, sem braquiblastos nas axilas, sésseis; lâminas 20-38×5-12 mm, estreito-elípticas, agudas 
no ápice, cuneadas ou atenuadas na base, herbáceas, pubérulas ou glabras na face superior, esparsamente pubérulas sobre a face inferior, ou com ambas superfícies glabras, pubérulas apenas ao longo das nervuras, margens ciliadas; nervuras secundárias 3-5 pares, com vascularização conspícua na face inferior. Ramos florais com 2-4 glomérulos axilares e terminais; glomérulos 7-13 mm diâm., densifloros, mais largos que compridos, os axilares subtendidos por 2 brácteas foliáceas, os terminais subtendidos por 4 brácteas em pares desiguais. Flores subsésseis, pedicelos ca. 0,6-1 mm compr. Hipanto obcônico, glabro. Cálice com pares de lobos fortemente desiguais, os maiores 2-2,5 mm compr., triangulares, carenados, pubescentes nas margens, os menores $0,5-1 \mathrm{~mm}$ compr., reduzidos a filamentos sub-hialinos, glabros. Corola 1,2-1,8 mm compr., hipocrateriforme; tubo 0,8-1,2 mm compr., glabro externamente, com ralo anel de tricomas na metade inferior interna; lobos 0,5-0,8 mm compr., ovado-triangulares, finamente papilosos externamente. Estames sésseis, inseridos na fauce da corola; anteras $0,4-0,6 \times$ ca. $0,2 \mathrm{~mm}$, subelípticas, subinclusas. Estilete 1,2-2 mm compr., filiforme. Cápsulas 1,6-2×1-1,6 mm, globosas, glabras; pedúnculo 1-1,2 mm compr. Sementes $0,6-1 \times 0,6-$ 0,8 mm, oblongóides, castanhas a castanho-claras; face dorsal sem depressões, exotesta fovéoloreticulada; face ventral com encaixe em forma de "X". Material examinado: BRASIL. MINAS GERAIS: Delfim Moreira, São Francisco dos Campos, 9.VI.1950, fl. e fr., M. Kuhlmann 2491 (SP, HUEFS). PARANÁ: Curitiba, Parque Iguaçu, 15.XII.1987, fl. e fr., J.M. Silva 443 (MBM). Capão da Imbuía, 4.III.1965, fl. e fr., L.T. Dombrowski \& Y.S. Kuniyos 1573 (MBM). RIO GRANDE DO SUL: Farroupilha, 7.II.1950 fl. e fr., B. Rambo s.n. (PACA 45724). SANTA CATARINA: Campo Belo do Sul, 14.I.1988, fl. e fr., A. Krapovickas \& C.L. Cristóbal 41994 (SPF, K). Material adicional examinado: ARGENTINA. MISIONES: Dept. Guarani, 265'ㅅ, 54¹8'W, 3.XI.1999, fl., S.G. Tressens et al. 6500 (CTES).

Mitracarpus brasiliensis assemelha-se a $M$. hirtus, da qual se distingue pelo caule alado, pelos lobos menores do cálice filiformes, muito reduzidos, inconspícuos, pelo hipanto glabro e por ser uma planta menos pubescente nas folhas e nas flores (Porto et al. 1977). Os caules geralmente alados na base, a forma das folhas e a ausência de braquiblastos nas axilas foliares relacionam esta espécie a $M$. robustus. A análise dos caracteres da exotesta das sementes também ajuda a suportar esta afinidade, pois ambas as espécies compartilham o mesmo tipo de escultura. Entretanto, M. brasiliensis se diferencia de $M$. robustus por apresentar porte herbáceo de 30-45 cm altura ( $v s$. subarbustivo com 70-200 cm altura em $M$. robustus), glomérulo terminal subtendido por 4 brácteas ( $v s$. glomérulo terminal subtendido por 2 brácteas), lobos menores do cálice filiformes ( vs. lobos menores do cálice estreitamente triangulares) e tubo da corola menor do que os maiores lobos do cálice (vs. tubo da corola superando os maiores lobos do cálice). Espécie com distribuição nas Regiões Sudeste e Sul do Brasil e noroeste da Argentina (Misiones). No Brasil, sua distribuição se estende do sudeste de Minas Gerais ao Rio Grande do Sul. Ocorre em campos degradados e beira de caminhos, com floração no verão e no outono. Quanto a seu status de conservação, a espécie é considerada não ameaçada [NE].

5. Mitracarpus buiquensis E.B. Souza \& Zappi, sp. nov. Tipo: BRASIL. PERNAMBUCO. Buíque, Chapada de São José, Faz. Laranjeiras, 08³7'S, 37010'W, 790 m, 5.V.1995, fl. e fr., A. Laurênio et al. 33 (holótipo PEUFR!; isótipo K!). Fig. 2 h-o

Haec species Mitracarpus salzmannianus similis, a qua 1-3 glomerulis per ramum floralem (nec 1-8), corolla 5-6 mm longa (vs. 3-5,2 mm longa), seminibus ventre formae litterae " $X$ " sulcatis dorsaliter cum depressioni cruciformi (vs. seminibus ventre formae littterae Ypsilontis inversae sulcati et dorsaliter non sulcatis) differt.

Erva 10-20 cm alt., ereta ou ascendente. Caules com ramos dispostos radialmente, formando touceiras, tetrágonos, marginados, híspidos sobre as margens, principalmente na base das folhas e região estipular, denso-vilosos nas faces. Bainha estipular 1-2 mm compr., híspida, com 5-9 setas, 2-4 mm compr., lineares, glabras. Folhas pseudoverticiladas pela presença de braquiblastos nas axilas, sésseis; lâminas 10-23×3$10 \mathrm{~mm}$, estreito-elípticas ou elípticas, agudo-apiculadas no ápice, atenuadas na base, cartáceas, estrigosas na face superior, híspidas na face inferior, principalmente ao longo das nervuras, escabras nas margens; nervuras secundárias geralmente em 3 pares. Ramos florais geralmente com 1-2 glomérulos, raramente com glomérulo terminal seguido por 2 glomérulos axilares; glomérulos 10-15 mm diâm., o terminal mais desenvolvido, globoso, subtendido por 4 brácteas foliáceas, os axilares menores, subtendidos por 2 brácteas foliáceas. Flores subsésseis, pedicelos 11,5 mm compr. Hipanto obcônico, pubérulo na porção superior. Cálice com pares de lobos desiguais, os maiores 3-3,5 mm, linear-lanceolados, acuminados, ciliados, os menores 1,8-2 mm compr., estreitamente triangulares, hialinos, acuminados. Corola 5-6 mm 

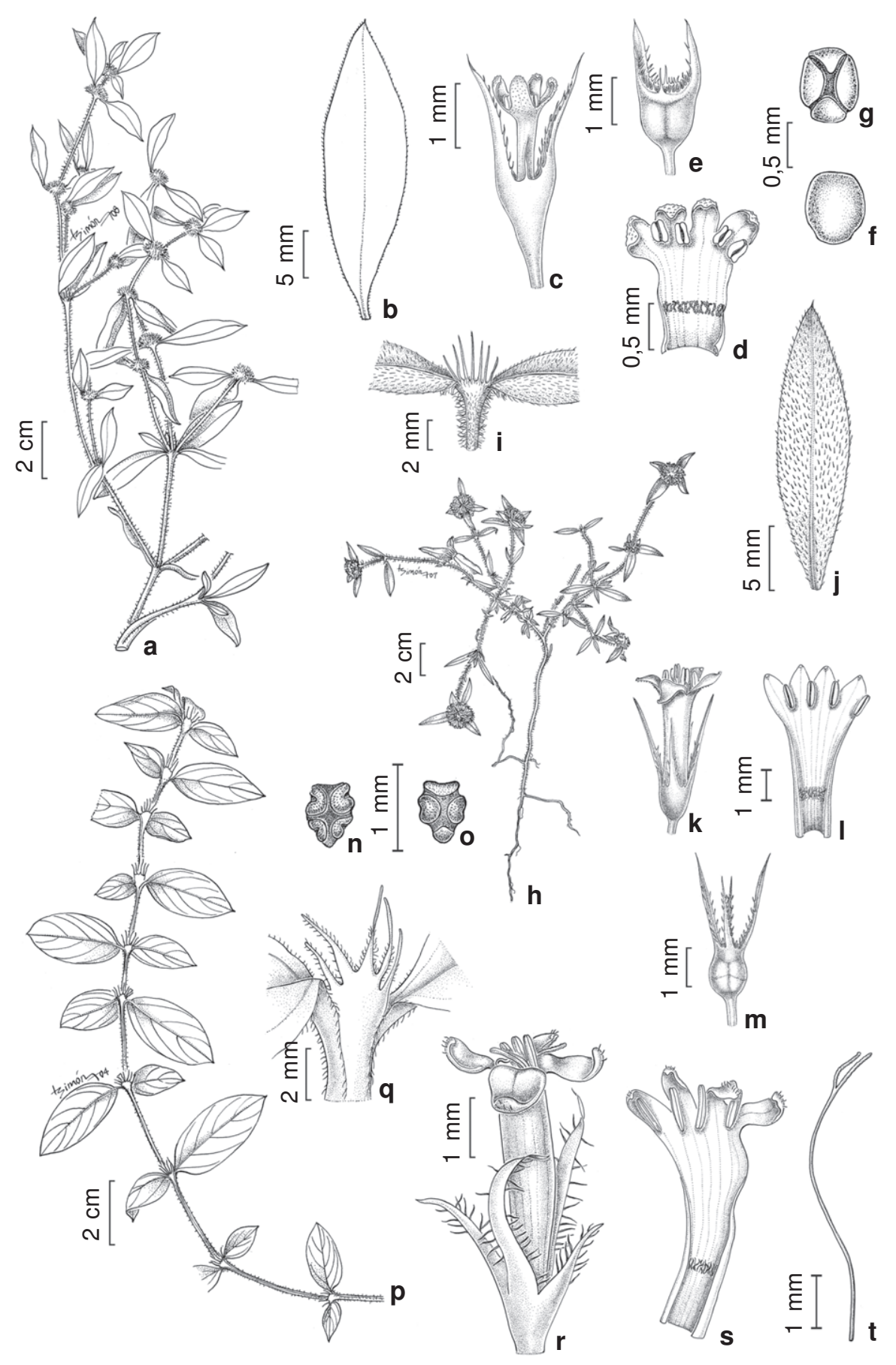

Figura 2 - a-g. Mitracarpus brasiliensis - a. ramo floral; b. folha; c. flor; d. corola aberta; e. cápsula jovem; f. semente, face dorsal; g. semente, face ventral. h-o. M. buiquensis - h. hábito; i. bainha estipular; j. folha; k. flor; 1. corola aberta; m. cápsula imatura; n. semente, face dorsal; o. semente, face ventral. p-t. M. diversifolius - p. ramo; q. bainha estipular; r. flor; s. corola aberta; t. estilete. (a Krapovickas \& Cristóbal 41994; b-g Rambo s.n. PACA 45724; h-o Laurênio et al. 33; p-t Thomas \& Sant'Ana 12485).

Figure 2 - a-g. Mitracarpus brasiliensis - a. flowering branch; b. leaf; c. flower; d. open corolla; e. young fruit; f. seed, dorsal view; g. seed, ventral view. h-o. M. buiquensis - h. habit; i. stipular sheath; j. leaf; k. flower; l. open corolla; m. young fruit; $\mathrm{n}$. seed, dorsal view; o. seed, ventral view. p-t. M. diversifolius - p. branch; q. stipular sheath; r. flower; s. open corolla; t. style. (a Krapovickas \& Cristóbal 41994; b-g Rambo s.n. PACA 45724; h-o Laurênio et al. 33; p-t Thomas \& Sant'Ana 12485). 
compr., (sub-)infundibuliforme; tubo 4-5 mm compr., externamente papiloso nos $2 / 3$ superiores, com anel de tricomas moniliformes no terço inferior interno; lobos $1 \mathrm{~mm}$ compr., ovados, agudo-apiculados, finamente papilados, com papilas maiores sobre o ápice. Estames subsésseis, inseridos na fauce da corola, filetes ca. $0,5 \mathrm{~mm}$ compr., anteras $1 \times$ ca. 0,3 $\mathrm{mm}$, lineares, subinclusas. Estilete 4,5-5 mm compr., filiforme; ramos estigmáticos ca, 0,5 mm compr. Cápsulas $1 \times 0,8-1 \mathrm{~mm}$, obcônicas; pedúnculo 2-3 mm compr., levemente pubérulas na porção superior. Sementes 0,8-1×0,5-0,6 mm, obovóides, castanhas; face dorsal com depressão cruciforme fortemente impressa, exotesta suavemente papilada; face ventral com depressão em forma de "X".

Mitracarpus buiquensis é distinguível pela corola (sub)infundibuliforme, densamente pubérula externamente, e sementes com exotesta suavemente papilada. Esta espécie tem afinidade com $M$. salzmannianus, da qual se diferencia por apresentar corola 5-6 mm compr., pubérula externamente ( $v s$. corola 3-5,2 mm compr., pubérulo-papilosa na metade superior) e sementes com depressão cruciforme dorsal e encaixe ventral em forma de "X" ( $v s$. sementes sem depressão cruciforme dorsal e encaixe ventral em forma de "Y-invertido"). Mitracarpus buiquensis é conhecido somente para a Chapada de São José, em Buíque, Pernambuco. Ocorre em caatinga arbustiva densa sobre solos arenosos profundos. A região de ocorrência desta espécie apresenta um alto número táxons endêmicos, tendo sido considerada uma das 27 áreas de extrema importância biológica para conservação dentro do Bioma Caatinga (Velloso et al. 2002). Quanto a seu status de conservação, a espécie é considerada ameaçada [EN] por apresentar populações esparsas, com poucos indivíduos, em área muito restrita.

6. Mitracarpus diversifolius E.B. Souza \& E.L. Cabral, sp. nov. Tipo: BRASIL. BAHIA: Boa Nova, Fazenda Cotermaia, entrance 1,2 km E of Boa Nova on road to Dario Meira, $14^{\circ} 22.419$ 'S, $40^{\circ} 11.305^{\prime} \mathrm{W}, 810 \mathrm{~m}$ alt., 18.V.2001, fl., W.W. Thomas \& S. Sant'Ana 12485 (holótipo CEPEC!; isótipo NY, SP!). Fig. 2 p-t

$A b$ omnibus speciebus generis habitu prostrato radicanti, foliis dimorphis in paribus dispositis, et inflorescentiis unilateralibus paucifloris differt.

Erva reptante, radicante nos nós. Caules 15$50 \mathrm{~cm}$ compr., tetrágonos, com ângulos alados, densamente pubescentes ao longo das margens. Bainha estipular 3-5 mm compr., glabra, com 6-7 setas, 2-5 mm compr., ciliadas. Folhas opostas sem braquiblastos nas axilas, pseudopecioladas, em pares desiguais, com as folhas maiores e menores alternadas ao longo dos ramos, as maiores 2,5-4×1,2-2,6 cm, lanceoladas, as menores 1,2-2,1 cm, ovadas, agudas no ápice, cuneadas ou levemente oblíquas na base, cartáceas, escabras nas margens, face superior esparsamente escabra, face inferior glabra; nervuras secundárias 2-4 pares. Ramos florais com 2-15 fascículos axilares; fascículos 3-7 mm diâm., unilaterais, paucifloros, subtendidos por 2 brácteas foliáceas. Flores sésseis. Hipanto obcônico, glabro. Cálice com pares de lobos desiguais, paleáceos, os maiores 2,22,5 mm compr., lanceolados, acuminados, ciliados, os menores 1-1,2 mm compr., estreito-triangulares, acuminados, ciliados. Corola 4-5 mm compr., hipocrateriforme; tubo 3-4 mm compr., glabro externamente, com anel de tricomas moniliformes no terço inferior interno; lobos $1 \mathrm{~mm}$ compr., ovados, glabros em ambas as faces ou esparsamente papilados no ápice. Estames subsésseis, inseridos na fauce da corola; anteras ca. 0,8-1 $\times 0,2-0,4$, oblongas, subinclusas. Estilete $4-5 \mathrm{~mm}$ compr.; filiforme; ramos estigmáticos ca. $1 \mathrm{~mm}$ compr. Cápsulas e sementes não observadas.

Mitracarpus diversifolius distingue-se de todas as outras espécies do gênero pelo seu hábito reptante e radicante nos nós, folhas dimórficas aos pares, e inflorescências unilaterais, paucifloras. Mitracarpus diversifolius é uma espécie somente conhecida para o município de Boa Nova, Bahia. Habita áreas úmidas no chão da floresta de cipó. Ao contrário da maioria das espécies de Mitracarpus, geralmente heliófitas, esta é uma esciófita com preferência por solos úmidos. Provavelmente endêmica da Mata de Cipó do sul da Bahia. Quanto a seu status de conservação, a espécie é considerada criticamente ameaçada [CR B2ab (iii, v)], especialmente pelo desmatamento e atividades agropecuárias locais.

7. Mitracarpus eichleri K. Schum. in Martius, Eichler \& Urban, Fl. Bras. 6(6): 86. 1888. Tipo: BRASIL. BAHIA: s.d., J. Blanchet 967 (holótipo B†; lectótipo G!, aqui designado; isolectótipo BM!). Fig. 3 a-h

Erva prostrada ou decumbente, com raízes fibrosas. Caules 35-65 mm compr., radiados, tetrágonos, glabros ou esparsamente pilosos. Bainha estipular $1 \mathrm{~mm}$ compr., esparsamente pubescente na margem, com 3(-4) setas (1-)2,5-3 mm compr., glabras. Folhas opostas, sem braquiblastos nas axilas, pseudopecioladas; lâminas 8-12×4-6 mm, ovadas 


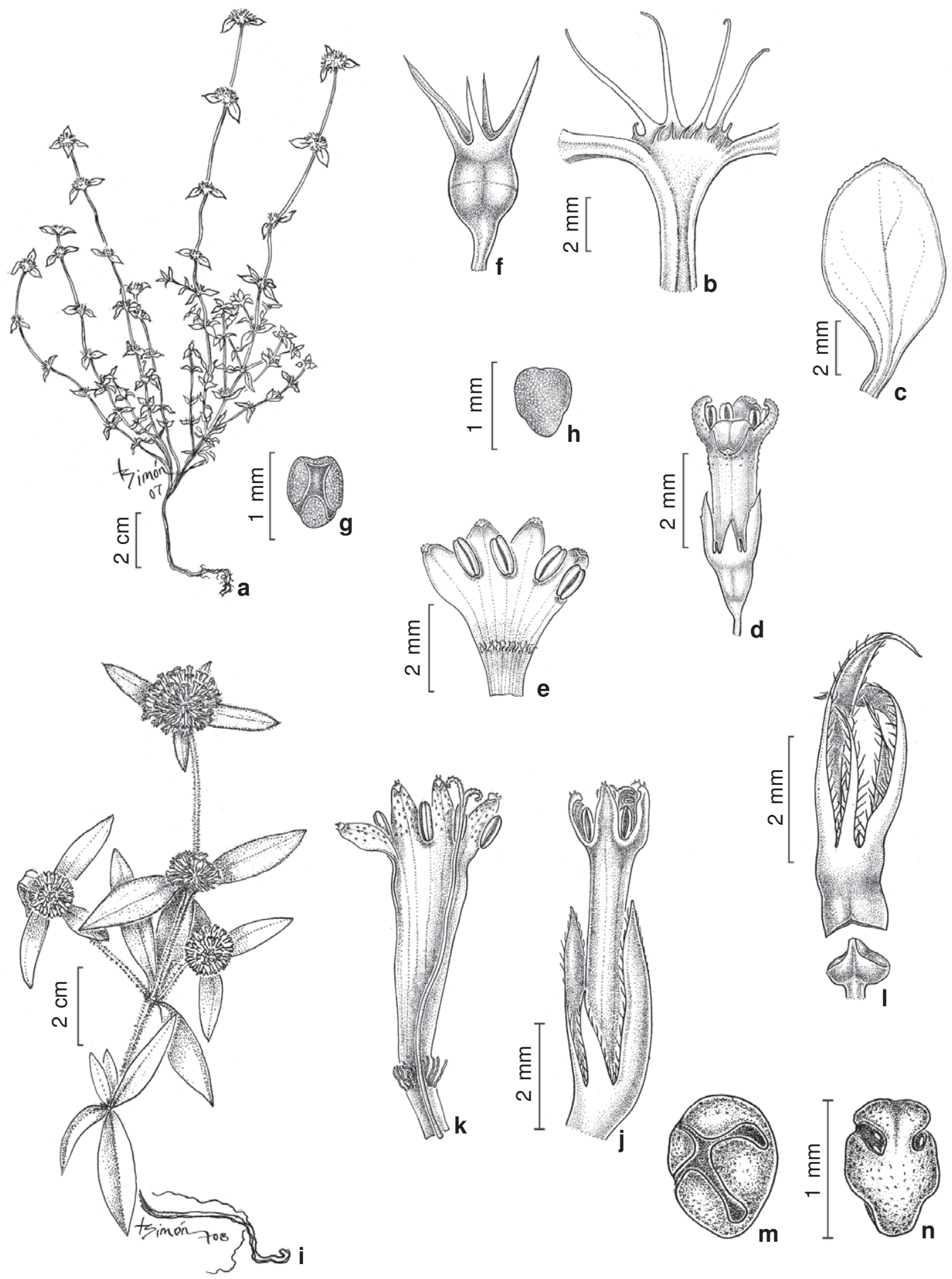

Figura 3 - a-h. Mitracarpus eichleri - a. hábito; b. bainha estipular; c. folha; d. flor; e. corola aberta; f. cápsula imatura; g. semente, face ventral; h. semente, face dorsal. i-n. M. eitenii - i. hábito; j. flor; k. corola aberta; 1. cápsula aberta. m-n. sementes; m. face dorsal; n. face ventral. (a-h Noblick 1703; i-n Eiten \& Eiten 4438).

Figure 3 - a-h. Mitracarpus eichleri - a. habit; b. stipular sheath; c. leaf; d. flower; e. open corolla; f. young fruit; g. seed, ventral view; h. seed, dorsal view. i-n. M. eitenii - i. habit; j. flower; k. open corolla; l. open fruit; m-n. seeds; m. dorsal view; n. ventral view. (ah Noblick 1703; i-n Eiten \& Eiten 4438). 
a largo ovadas, agudas no ápice, atenuadas na base, semisuculentas, glabras em ambas as faces ou escabras na face superior, esparsamente escabras na face inferior, margens espessadas, glabras; nervuras secundárias 3-5 pares, levemente perceptíveis na face superior ou inconspícuas, nervura principal impressa na face superior e proeminente na face inferior. Ramos florais geralmente com glomérulos solitários, ou com glomérulo terminal seguido por 1-3 glomérulos axilares; glomérulos 5-10 mm diâm., subtendidos por 2-4 brácteas foliáceas. Flores subsésseis; pedicelos ca. $1 \mathrm{~mm}$ compr. Hipanto obcônico, glabro. Cálice com pares de lobos desiguais, os maiores 1,5-2 mm compr., lanceolados, glabros ou com raros dentículos esparsos nas margens, carenados, agudo-setulosos, ou oblongos com o ápice portando dentículos laterais, os menores 1-1,5 mm compr., estreitotriangulares, glabros, hialinos. Corola 3-5 mm compr., hipocrateriforme; tubo 2-4 mm compr., pubérulo na metade superior externa, com anel de tricomas moniliformes na região mediana interna; lobos 1-1,5 mm compr., oblongos. Estames subsésseis, inseridos na fauce da corola; anteras ca. $0,8 \times 0,4 \mathrm{~mm}$ compr., oblongas, subinclusas. Estilete 3-4,5 mm compr., filiforme; ramos estigmáticos ca. $0,5 \mathrm{~mm}$ compr. Cápsulas ca. 1,8 $\times 1 \mathrm{~mm}$, obovóides, glabras, pedúnculo 0,8-1 mm compr. Sementes ca. 0,7-0,8× 0,5 mm, oblongóides ou obovóides, castanhas; face dorsal sem depressões, exotesta fovéolo-reticulada; face ventral com encaixe em forma "Y-invertido", amplamente coberto por excrescência granular.

Material selecionado: BRASIL. BAHIA: Salvador, Itapuã, $12^{\circ} 56$ 'S, $38^{\circ} 21^{\prime}$ 'W , 2.III.1980, fl. e fr., L.R. Noblick et al. 1703 (ALCB). Mata de São João, 9.VI.1996, fl. e fr., R. Soeiro 15 (HBR). ESPÍRITO SANTO: Conceição da Barra, Ilha de Gurupi, 1.XI.1999, fl. e fr., M. Canal et al. 216 (K). RIO DE JANEIRO: Marambaia, 21.I.1917, fl., A. Lutz 1175 (R). RIO GRANDE DO NORTE: Natal, Parque das Dunas, 25.VIII.1980, fl. e fr., PPD 35, 39 (R).

Mitracarpus eichlerié uma espécies relacionada com M. salzmannianus, com a qual compartilha o mesmo tipo de encaixe ventral das sementes ("Yinvertido") e o mesmo padrão de ornamentação da exotesta (com células poligonais e paredes anticlinais onduladas ou retas). Considerando que o holótipo foi destruído em Berlim, o isótipo do mesmo, depositado no Jardim Botânico de Genebra $(G)$, foi escolhido como lectótipo (CINB, Art. 9.10). A espécie é restrita ao litoral do Brasil, nos estados do Rio Grande do Norte, Bahia, Espírito Santo e Rio de Janeiro. É uma heliófita, característica da vegetação pioneira nas restingas e dunas, sobre solos arenosos profundos. Quanto a seu status de conservação, a espécie é considerada vulnerável [VU A3c]. Devido à crescente ocupação do litoral, impulsionada pela especulação imobiliária, os hábitats ocupados por esta espécie têm desaparecido ou sido alterados.

8. Mitracarpus eitenii E.B. Souza \& E.L.Cabral, sp. nov. Tipo: BRASIL. MARANHÃO: Loreto, "Ilha de Balsas region, between the Rios Balsas and Parnaíba, Fazenda "Morros", Chapada Alta", ca. $35 \mathrm{~km} \mathrm{~S}$ of Loreto, along trail to Santa Bárbara, 7²4'S, 454' W, 350-400 m, 29.IV.1962, fl. e fr., G. Eiten \& L.T. Eiten 4438 (holótipo UB!; isótipo SP!, K!). $\quad$ Fig. 3 i-n

Haec species Mitracarpus longicalyx similis, sed corollae lobis intus puberulis (versus glabris in M. longicalyx) et seminibus sine depressionibus semicircularibus dorsalibus differt.

Erva ou subarbusto (7-) $15-50 \mathrm{~cm}$ alt., ereto. Caules tetrágonos, densamente híspido-vilosos, com tricomas longos, híspidos, ao longo das margens, tricomas curtos, adpressos, nas faces. Bainha estipular 1,5-2 mm compr., glabra, pubescente somente na área de inserção das setas, com 5-7 setas, 1,5$2 \mathrm{~mm}$ compr., glabras. Folhas opostas, sem braquiblastos nas axilas, sésseis; lâminas 15-45 × 5-17 mm, (estreito-) elípticas, agudas ou acuminadomucronadas no ápice, atenuadas na base, cartáceas, densamente ciliadas nas margens, levemente revolutas, face superior estrigosa, face inferior glabra sobre a superfície, híspida ao longo das nervuras; nervuras secundárias 4-5 pares, levemente impressas na face superior, proeminentes na fase inferior. Ramos florais com (1-)2-4 glomérulos terminais e axilares; glomérulos (7-)13-20 mm diâm., mais largos do que compridos, subtendidos por 2-8 brácteas foliáceas; glomérulo terminal geralmente mais desenvolvido do que os axilares. Flores subsésseis, pedicelos ca. 0,5 mm compr. Hipanto obcônico, glabro. Cálice com pares de lobos desiguais, os maiores 3-4 mm compr., lanceolados, ciliados, os menores 1-2 mm compr., estreito-triangulares, ciliados. Corola 4-7 mm compr., hipocrateriforme; tubo 3-5 mm compr., pubérulo no terço superior externo, com anel de tricomas moniliformes no terço inferior interno; lobos 1-2 mm compr., ovados, densamente pubérulos na face interna. Estames sésseis, inseridos na fauce da corola; anteras $0,8-$ $1 \times$ ca. 0,3 mm compr., subelípticas, subinclusas. Estilete 5-6 mm compr., filiforme; ramos estigmáticos ca. 1 mm compr. Cápsulas 1,8-2×ca. 1 mm, obcônicas; pedúnculo ca. $1 \mathrm{~mm}$ compr. Sementes ca. $0,8 \times 0,6 \mathrm{~m}$, obovóides, castanho-claras; face dorsal sem 
depressão cruciforme, exotesta lisa, finamente reticulada; face ventral com encaixe em forma de " $X$ ". Material examinado: BRASIL. MARANHÃO: Loreto, "Ilha de Balsas" region, between the Rios Balsas and Parnaíba, about $35 \mathrm{~km}$ South of Loreto, $07^{\circ} 23^{\prime} \mathrm{S}$, 4504'W, 20.VI.1962, fl., G. Eiten \& L.T. Eiten 4340 (UB).

Mitracarpus eitenii apresenta glomérulo terminal geralmente mais desenvolvido do que os axilares e os lobos da corola são densamente pubérulos na face interna. Alguns exemplares de herbário são morfologicamente similares aos de $M$. longicalyx. Contudo, esta última espécie tem corola com lobos internamente glabros e sementes com depressões semicirculares dorsais. Mitracarpus eitenii é conhecida para a região do vale do Rio das Balsas, no município de Loreto, Maranhão. Habita áreas abertas, no topo de platôs, crescendo isoladamente entre rochas, sobre solos marrons, siltosos. Esta espécie tem sua área de distribuição no bioma Cerrado. O epíteto é uma homenagem ao Dr. George Eiten, referência mundial em pesquisas sobre o Cerrado, professor aposentado da Universidade de Brasília. Não há dados suficientes [DD] para avaliar a categoria de conservação desta espécie, pois é conhecida apenas de duas coletas feitas nos anos 1960.

9. Mitracarpus eritrichoides Standl., Publ. Field Mus. Nat. Hist., Bot. Ser. 11:223. 1936. Tipo: BRASIL. MATO GROSSO: Diamantino, nascentes do Rio Paraguai, XII.1844, fl. e fr., H.A. Weddell 3090 (holótipo P!).

Fig. 4 a-h

Erva de pequeno porte, prostrada ou decumbente. Caules 2,5-7 cm compr., cilíndricos a subquadrangulares, flexuosos, delgados, densamente híspidos, com tricomas longos intercalados com tricomas menores, vilosos. Bainha estipular 0,5-1 mm compr., com (2-)3-5 setas $1 \mathrm{~mm}$ compr., glabras. Folhas opostas sem braquiblastos nas axilas, sésseis; lâminas 4-13×1-3 mm, (estreito-)elípticas, agudo-mucronadas no ápice, obtusas a agudas na base, cartáceas, com margens espessadas, ciliadas na metade superior, face superior glabra a pubescente, com tricomas longos, hialinos, face inferior pubescente ao longo da nervura principal; nervuras secundárias inconspícuas. Ramos florais geralmente com um glomérulo terminal, raramente com glomérulo subterminal, 3-7 mm diâm., globosos, subtendidos por 2-4 brácteas foliáceas. Hipanto obovóide, pubérulo no ápice. Flores subsésseis. Cálice com pares de lobos desiguais; os maiores 1,5-2 mm compr., lanceolados, carenados, ciliados nas margens; os menores 1-1,2 mm compr., estreito-triangulares, hialinos. Corola 2-2,4 mm compr.; hipocrateriforme, alva; tubo 1-1,2 mm compr., glabro externamente, com anel de tricomas moniliformes no terço inferior interno; lobos 0,8-1 mm compr., ovados, pubérulos no ápice, papilosos na face interna. Estames subsésseis; anteras 0,5-0,7 × ca. 0,3 mm compr., oblongas, subinclusas. Estilete 2-2,5 mm compr., ramos estigmáticos inconspícuos. Cápsulas ca. $1 \times$ 1,2 mm, globosas, pubérulas no ápice. Sementes 0,5-0,6 × ca. 0,5 mm, globosas, castanhas a castanho-escuras; face dorsal sem depressões, exotesta fovéolo-reticulada; face ventral com encaixe em forma de " $X$ ".

Material examinado: BRASIL. GOIÁS: Faina, Serra de Santa Rita, Dto. Jeroaquara, 26.II.1972, fl., J.A. Rizzo 7700 (HUFG, HUVA). MATO GROSSO: Cuiabá, Chapada dos Guimarães, $15^{\circ} 28^{\prime} 49^{\prime \prime S}, 56^{\circ} 03$ '31'W, 20.IV.2005, fl. e fr., E.B. Souza et al. 1263, 1264, 1265 (HUEFS). Barra do Garças, 6.V. 1975, fl. e fr., W.R. Anderson 9866 (W). Mitracarpus eritrichoides está relacionada com M. parvulus, da qual se distingue pela corola 2-2,4 mm compr. (vs. 1-1,2 mm compr.) e pelas folhas de margens espessadas (vs. margens sem espessamentos). Ocorre nos estados de Goiás e Mato Grosso, com poucos registros em herbário. Mitracarpus eritrichoides é uma erva heliófita que ocorre em áreas de campo cerrado sobre solos de textura arenosa com concreções lateríticas. Quanto a seu status de conservação, a espécie é considerada vulnerável [VU D2], sendo encontrada em poucas localidades, formando populações muito restritas, e estando sujeita aos efeitos das atividades agropecuárias em seu habitat natural.

10. Mitracarpus frigidus (Willd. ex Roem. \& Schult.) K. Schum., Fl. Bras. 6(6): 81. 1888. Spermacoce frigida Willd. ex Roem. \& Schult., Syst. Veg. 3: 531. 1818. Tipo: VENEZUELA. Silla de Cavacas, A. Humboldt \& M.A. Bonpland s.n. (holótipo B-Willd 2623, foto!).

Fig. 4 i-q

Mitracarpus humboldtianus Cham. \& Schltdl., Linnaea 3: 58. 1828. Tipo: VENEZUELA. Silla de Cavacas, A. Humboldt \& M.A. Bonpland s.n. (lectótipo B-Willd 2623, foto!, aqui designado); BRASIL. RIO DE JANEIRO: F. Sellow s.n. (síntipo $\mathrm{B} \dagger)$, nom. illeg para $M$. frigidus.

Mitracarpus fruticosus Standl., Lloydia 2: 215. 1939. Mitracarpus frigidus var. fruticosus (Standl.) Steyerm., Mem. New York Bot. Gard. 23: 781. 1972. Tipo: GUIANA. A.C. Smith 3642 (holótipo F; isótipo MO, U!, W!).

Mitracarpus frigidus var. andinus Steyerm., Mem. New York Bot. Gard. 23: 779. 1972. Tipo: VENEZUELA. Distrito Federal, O. Kuntze 1643 (holótipo NY). 
Mitracarpus frigidus var. orinocensis Steyerm., Mem. New York Bot. Gard. 23: 780. 1972. Tipo: VENEZUELA. Amazonas, J.J. Wurdack \& L.S. Andderley 42698 (holótipo NY, foto!; isótipo VEN).

Mitracarpus frigidus var. peruvianus Steyerm., Mem. New York Bot. Gard. 23: 780. 1972. Tipo: PERU. Amazonas, E.L. Evinger 513 (holótipo NY, foto!; isótipo US, VEN).

Erva perene ou subarbusto 0,3-1(-2) $\mathrm{m}$ alt., ereto ou ascendente. Caules fortemente tetrágonos, alados, glabros ou pubérulos nas faces, híspidos ou pubescentes sobre as alas, tricomas geralmente retrorsos, mais densos na região estipular. Bainha estipular 2-3 mm compr., coriácea, glabra ou pubérula, com 4-8(-12) setas, 2-7(-12) mm compr., estreitotriangulares, acuminadas, glabras, geralmente com coléter apical. Folhas pseudoverticiladas pela presença de braquiblastos nas axilas, sésseis; lâminas 11-9 × (2-)5-20 mm, lanceoladas ou linearlanceoladas, raramente lineares, agudo-mucronadas no ápice, atenuadas ou cuneadas base, cartáceas, face superior escabra, estrigosa ou glabra, face inferior escabra até glabra sobre a superfície laminar, glabras ou pilosas sobre as nervuras, margens ciliadas, escabras ou raramente glabras; nervuras secundárias 2-3 pares, ou inconspícuas. Ramos florais geralmente com um glomérulo terminal, ou seguido por 1-2 glomérulos axilares, (10-)12-19(-25) mm diâm., subtendidos por 2-4 brácteas foliáceas, reflexas. Flores subsésseis, pedicelo inconspícuo. Hipanto obcônico, glabro ou pubérulo no ápice. Cálice com pares de lobos desiguais, os maiores 3-5 mm compr., (linear-) lanceolados, longamente acuminados, ciliados nas margens, os menores (1,2-)2-3 mm compr., estreito-triangulares, hialinos, longamente acuminados, ciliados nas margens. Corola (3,5-)5-9 mm compr., hipocrateriforme; tubo (3-)4-7 mm compr., (pubérulo-) papiloso externamente, com anel de tricomas moniliformes no terço inferior interno; lobos 1,5-2 mm compr., ovados, subobtusos até agudos, papilosos ou pubérulos externamente, esparsa ou densamente pubérulos internamente. Estames inseridos na fauce da corola; filetes $0,5-1 \mathrm{~mm}$ compr.; anteras $1-1,5 \times$ ca. $0,3 \mathrm{~mm}$, lineares, subinclusas. Estilete (3-)6-9 mm compr., filiforme; ramos estigmáticos 0,5-1 mm compr. Cápsulas 1,5-2 × ca. 0,5-1,5 mm, obcônicas, glabras ou pubérulas na parte superior. Sementes 1-1,2× ca. 0,8 mm, oblongóides ou globosas, castanhas a castanho-escuras; face dorsal com depressão cruciforme profundamente impressa, exotesta fovéolo-reticulada; face ventral com encaixe em forma de "X".
Material selecionado: BRASIL. AMAZONAS: Pico Rondon, 01³2'N, 6248'W, 3.II.1984, fl. e fr., J. Pipoly et al. 6611 (K). BAHIA: Abaíra, 13²19'S, 41ํ54'W, 20.XI.1993, fr., W. Ganev 2528 (HUEFS, K). Serra da Serrinha, 12²0'S, 41 ${ }^{\circ} 51^{\prime} \mathrm{W}, 26 . I V .1994$, fl. e fr., W. Ganev 3135 (HUEFS, K). ESPÍRITO SANTO: Itaguaçu, Alto Limoeiro, 10.V.1946, fl. e fr., A.C. Brade et al. 18059 (RB). PERNAMBUCO: Buíque, Parque Nacional de Catimbau, 22.IX.2004, fl. e fr., A.M. Miranda \& M. Grillo 4465 (HUEFS). PIAUÍ: São João do Piauí, 08²1'29”S, 42¹4'48”'W, 14.IV.1994, fl. e fr., M.S. Bona \& J.H. Carvalho 462 (CTES). PARAÍBA: Serra Branca, 07³0'29'S, 3645'49'W, 21.V.2002, fl., M.F. A gra et al. 5929 (HUEFS). MINAS GERAIS: Itabirito, Serra do Itabirito, 8.II.1968, fl. e fr., H.S. Irwin et al. 19600 (K). RIO DE JANEIRO: Porciúncula, Pedra da Elefantina, fl., J.P.P. Carauta et al. 4518 (UB). RORAIMA: Serra da Lua, 02²5-29'N, 60¹1-14'W, 24.I.1969, fl., G.T. Prance et al. 9431 (K). SANTA CATARINA: Mafra, 7-9 km W of Tinguí on the road to Mafra, 2.II.1957, fl. e fr., L.B. Smith \& R.M. Klein 10609 (R).

Material adicional examinado: VENEZUELA. Los Flores, Sierra de El Avila, 15.XII.1938, fl. e fr., A.H.G. Alston 5537 (U).

Mitracarpus frigidus é similar a M. robustus; contudo, a primeira espécie é distinguível principalmente por apresentar folhas pseudoverticiladas ( $v s$. opostas), inflorescências com 1-3 glomérulos por ramo floral (vs. 2-14), glomérulo terminal subtendido por quatro brácteas (vs. duas) e sementes com depressão cruciforme dorsal ( $v s$. sementes sem depressões dorsais). $\mathrm{O}$ exame dos espécimes e/ou fotos dos tipos das diversas variedades publicadas sob $M$. frigidus indicam um gradiente de variação morfológica que expressa os aspectos adaptativos das populações ao longo da ampla faixa de distribuição desta espécie. Os caracteres florais e aqueles relativos a frutos e sementes são, contudo, coerentes com o conceito de $M$. frigidus. Vale salientar, que M. humboldtianus é um nome rejeitado para M. frigidus, uma vez que fere o Art. 51.1 do CINB (vide comentários sob $M$. robustus). As coleções Humboldt \& Bonpland s.n. e Sellow s.n, indicadas na publicação de Mitracarpus humboldtianus, são sintipos. Dentre elas, a coleção remanescente de Humboldt \& Bonpland s.n. foi, então, escolhida como lectótipo (CINB, Art. 9.10). Espécie com ampla distribuição, ocorrendo na Colômbia, Venezuela, Guiana Francesa e Brasil. No Brasil, ocorre desde o estado de Roraima até o de Santa Catarina (Delprete et al. 2005), como espécie heliófita até esciófita, encontrada de $150 \mathrm{~m}$ a $2.970 \mathrm{~m}$ altitude. Habita solos arenosos, geralmente com preferência por áreas mais úmidas, sobre afloramentos rochosos e 

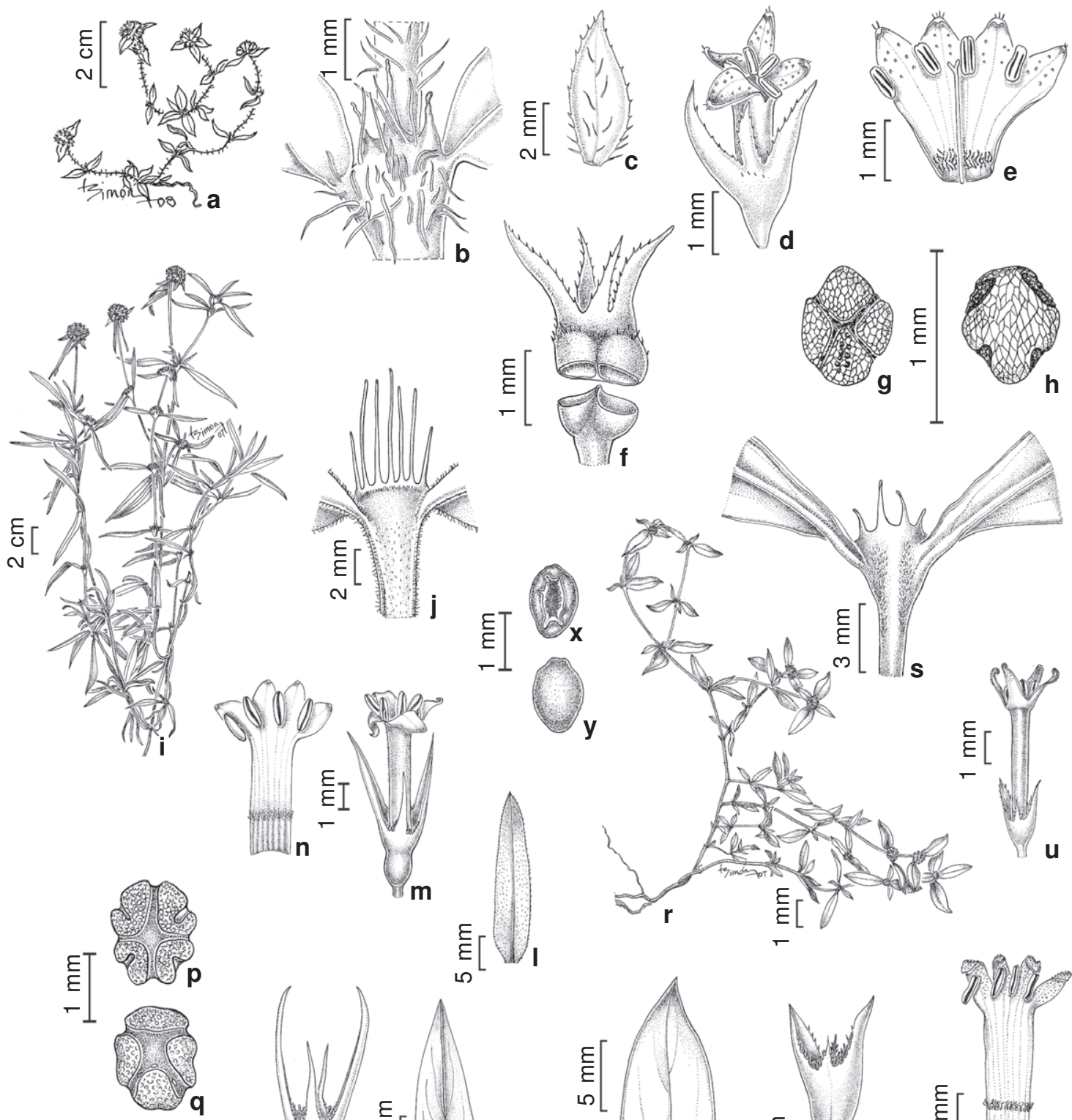

Eૉ
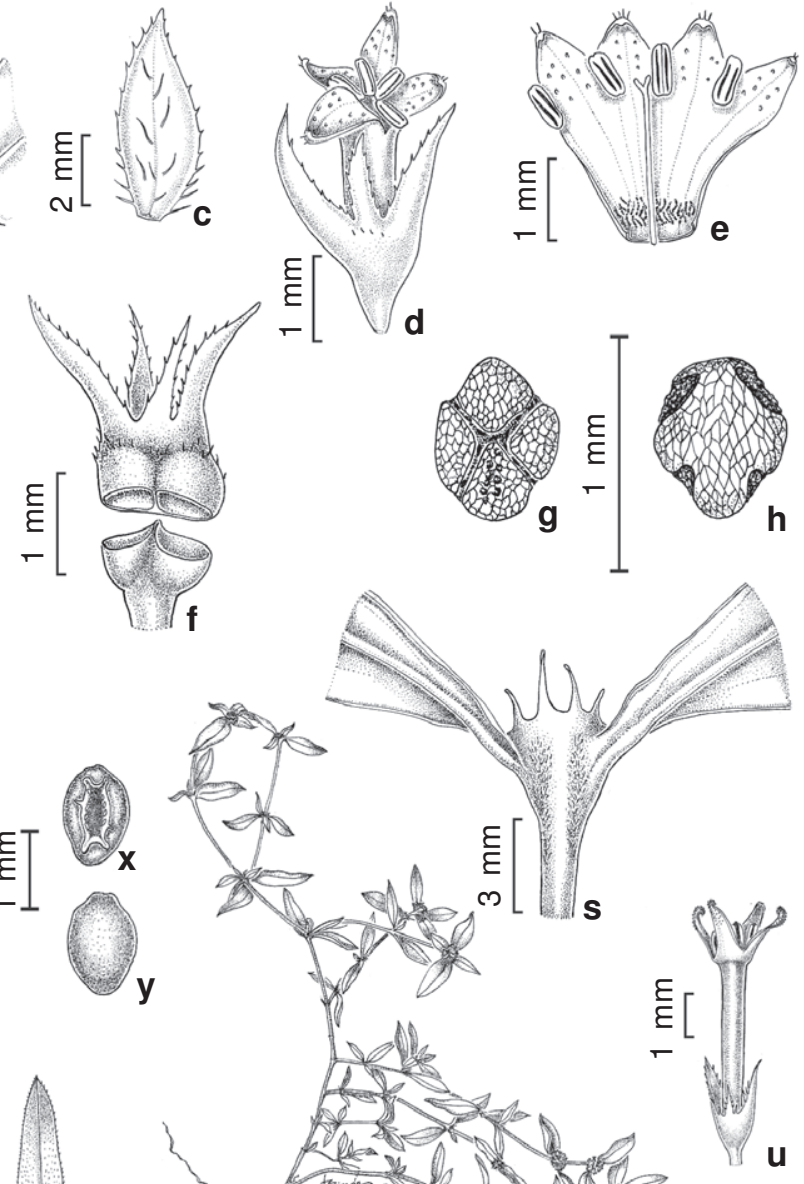

Figura 4 - a-h. Mitracarpus eritrichoides - a. hábito; b. bainha estipular; c. folha; d. flor; e. corola aberta; f. cápsula aberta; g. semente, face ventral; h. semente, face dorsal. i-q. M. frigidus - i. ramo floral; j. bainha estipular; k. folha glabra. 1. folha pilosa; $\mathrm{m}$. flor; $\mathrm{n}$. corola aberta; o. cápsula imatura; p. semente, face dorsal; q. semente, face ventral. r-y. M. lhotzkyanus - r. hábito. s. bainha estipular. t. folha. u. flor; v. corola aberta; w. cápsula aberta; x. semente, face ventral; y. semente, face dorsal. (a-h Souza et al. 1265; i Alston 5537; j-k Ganev 2528; 1-q Ganev 3135; r Lobão et al. 6A; s Carauta 166; t Lhotzky 13; u-w Ferreira 9; x-y Lhotzky 13).

Figure 4 - a-h. Mitracarpus eritrichoides - a. habit; b. stipular sheath; c. leaf; d. flower; e. open corolla; f. open fruit; g. seed, ventral view; h. seed, dorsal view. i-q. M. frigidus - i. flowering branch; j. stipular sheath; k. glabrous leaf. 1. pubescent leaf; m. flower; n. open corolla; o. young fruit; p. seed, dorsal view; q. seed, ventral view. r-y. M. lhotzkyanus - r. habit. s. stipular sheath. t. leaf. u. flower; v. open corolla; w. open fruit. x. seed, ventral view; y. seed, dorsal view. (a-h Souza et al. 1265; i Alston 5537; j-k Ganev 2528; 1-q Ganev 3135; r Lobão et al. 6A; s Carauta 166; t Lhotzky 13; u-w Ferreira 9; x-y. Lhotzky 13). 
inselbergs. Ocorre também como planta ruderal em capoeiras, vegetação secundária e margens de caminho. Quanto a seu status de conservação, a espécie é considerada não ameaçada [NE].

11. Mitracarpus hirtus (L.) DC., Prodr. 4: 572. 1830. Spermacoce hirta L., Sp. Pl. ed. 2. 148. 1762. Tipo: JAMAICA, s.d, s.c. (holótipo LINN. 125.4 foto!).

Mitracarpus scaber Zucc. ex Schult. \& Schult. f., Mant. 3. 210, 399. 1827. Tipo: SENEGAL. "In sabulosis prope Forte Luis", J.G. Zuccarini s.n. (holótipo B †; duplicatas não localizadas).

Mitracarpus diffusus (Willd. ex Roem. \& Schult.) Cham. \& Schltdl. Linnaea 3: 363. 1828. Spermacoce diffusa Willd. ex Roem. \& Schult., Syst. Veg. 3: 531. 1818; H.B.K. Nov. Gen. \& Sp. 3: 343. 1819. Tipo: VENEZUELA. "in ripa fluminis Apure, provinciae Varinensis". A. Humboldt \& M.A. Bonpland s.n. (holótipo B-Willd 2630, foto!), syn. nov.

Mitracarpus villosus (Sw.) DC., Prodr. 4: 572. 1830. Spermacoce villosa Sw., Prodr. Veg. Ind. Occ. 29: 1788. Tipo: JAMAICA. O. Swartz s.n. (BM!)

Mitracarpus senegalensis DC., Prodr. 4: 572. 1830. Tipo: SENEGAL. C.H. Bacle, G.S. Perrottet \& F.M.R. Leprieur s.n. (G!). GUINÉ. P. Thonnig s.n. (G!), nom. Illeg. para Staurospermum verticillatum. Mitracarpus verticillatus (Schumach. \& Thonn.) Vatke, Linnaea 40: 196. 1986. Staurospermum verticillatum Schumach. \& Thonn., Beskr. Guin. Pl.: 73. 1827. Tipo: GUINÉ. H.C.F. Schumacher s.n. (C).

Erva $15-50(-70) \mathrm{cm}$. alt., ereta, ascendente ou decumbente. Caules cilíndricos, subtetrágonos a tetrágono-marginados, solitários ou com 1-7 ramificações laterais, às vezes apicalmente flexuosos, geralmente com manchas vináceo-púrpuras nos entrenós, híspido-vilosos nas margens, vilosos nas faces, ou densamente vilosos a glabrescentes. Bainha estipular 2-3 mm compr., glabra, com 5-9(-11) setas, 2-4 mm compr. Folhas opostas sem braquiblastos nas axilas, sésseis; lâminas (15-)20-30(-40)×(2)4$10(-12) \mathrm{mm}$, (estreito-)elípticas, agudo-mucronadas no ápice, atenuadas ou cuneadas na base, cartáceas, ciliadas na margem, denso-estrigosas, escabras a glabrescentes na face superior, denso-híspidas ao longo das nervuras, estrigosas a escabras até glabrescentes na face inferior; nervuras secundárias 3-4 pares. Ramos florais com (1-)2-3-(5) glomérulos terminais e axilares, 5-15 mm diâm., subtendidos por 2-4 brácteas foliáceas, patentes. Flores subsésseis, pedicelos ca. 0,5 mm compr. Hipanto obcônico, piloso na metade superior. Cálice com pares de lobos desiguais, os maiores 1,5-2 mm compr., lanceolados, ciliados nas margens e ao longo da nervura, os menores 1-1,2 mm compr., (estreito-) triangulares, ciliados. Corola (1,2-)2-3 mm compr., hipocrateriforme; tubo 1,4-2 mm compr., pubérulopapiloso ou esparsamente piloso na metade superior externa, com anel ralo de tricomas moniliformes na região mediana interna. Estames sésseis, inseridos na fauce da corola; anteras ca. $0,4-0,5 \times 0,2-0,3 \mathrm{~mm}$. subelípticas, subinclusas. Estilete 1,5-2,2 $\mathrm{mm}$ compr., filiforme; ramos estigmáticos ca. 0,3-0,5 mm compr. Cápsulas 2-2,3 × ca. $1 \mathrm{~mm}$, turbinadas, pilosas na metade superior; pedúnculo $1-1,2 \mathrm{~mm}$ compr. Sementes 0,6-0,8×0,5-0,6 mm, oblongóides ou subelipsóides, face dorsal sem depressões, exotesta fovéolo-reticulada; face ventral com encaixe em forma de "X".

Material selecionado: BRASIL. ALAGOAS: 1838, fl. e fr., G. Gardner 1334 (K). AMAZONAS: Juruá, Vila Bonfim, X.1900, fl. e fr., E. Ule 5129 (K). BAHIA: Barreiras, 1206'43"S, 4509'47'W, 13.IV.2005, fl. e fr., E.B. Souza et al. 1136, 1138 (HUEFS). CEARÁ: Quixadá, Faz. Não-me-Deixes, 15.IV.2000, fl., R.C. Costa s.n. (EAC 32009). DISTRITO FEDERAL: Faz. Água Limpa, 10.IV.1980, fl., H.L. César 435 (EAC). ESPÍRITO SANTO: Itabapoana, 19.II.1976, fl., A. Glaziou 9920 (P). GOIÁS: Caiapônia, $23 \mathrm{~km}$ E of Caiapônia on road to Montividéu, 4.II.1959, fl. e fr., H.S. Irwin et al. 2577 (R). MATO GROSSO: Chapada dos Parecis, 1409'43"S, 5708'11"W, 21.IV.2005, fl., E.B. Souza et al. 1292 (HUEFS). MINAS GERAIS: Joaquim Felício, 17¹1'34”S, 44¹1'56”W, 30.III.2005, fl. e fr., E.B. Souza et al. 1057 (HUEFS). PARÁ: Monte Alegre, 29.X.1873, fl., J.W.H. Trail 437 (K). PERNAMBUCO: Gravatá, Serra das Russas, 2.VIII.1996, fl. e fr., E.B. Souza 132, 141 (PEUFR). RIO DE JANEIRO: Petrópolis, road to Faz. Inglesa, III.1951, fl., I. Rocha e Silva 67 (R). RIO GRANDE DO SUL: Santiago, 4.IV.1975, fl., M.L. Porto 1412 (ICN). SANTA CATARINA: Porto União, Pinheiral, 20.XII.1956, fl. e fr., L.B. Smith \& R. Reitz 8873 (R). SÃO PAULO: Itapeva, Itanguá, I.1958, fl. e fr., J. Vidal s.n. (R 147013). PARANÁ: Volta Grande, 4.II.1904, fl. e fr., Dusen s.n. (R 24646). TOCANTINS: Arraias, rod. Arraias-Paranã, 12.II.1994, fl. e fr., G. Hatschbach et al. 60465 (MBM).

Mitracarpus hirtus é reconhecível por apresentar folhas opostas, elípticas ou estreito-elípticas, de margens ciliadas, corola com tubo menor do que os maiores lobos do cálice, cápsulas pilosas no ápice e sementes sem depressões dorsais. Apresenta muitas variações fenotípicas no porte, na forma e no tamanho das folhas e densidade e qualidade do indumento. A grande variação inter e intrapopulacional levaram à publicação de alguns binômios, que refletem os diversos morfotipos encontrados dentro de sua faixa de distribuição. É o caso de $M$. diffusus, que representa um morfotipo com caules prostrados ou 
decumbentes e com corolas diminutas. Os caracteres da cápsula e das sementes são, entretanto, similares em todos os exemplares examinados, o que não justifica uma separação em nível de espécie. É a espécie mais amplamente distribuída do gênero, ocorrendo desde o sul dos Estados Unidos, América Central e Caribe até o norte da Argentina. Sua ocorrência como planta introduzida é reportada para a África, Ásia e Ilhas do Pacífico (Fosberg et al. 1993; Verdcourt 1975; Nicolson 1977). No Brasil, sua distribuição é ampla, sendo registrada praticamente em todos os estados. Mitracarpus hirtus é uma planta heliófita até esciófita e não apresenta grandes preferências por condições físicas de solo. Habita margens de caminhos, capoeiras, orla de matas e áreas de cultivo e pastagens. Encontrada desde o nível do mar até $1500 \mathrm{~m}$ de altitude. Quanto a seu status de conservação, a espécie é considerada não ameaçada [NE].

12. Mitracarpus lhotzkyanus Cham., Linnaea 9: 219. 1834. Tipo: BRASIL. RIODEJANEIRO: IX.1829, fl. e fr., J. Lhotzky 13 (holótipo LE; isótipo K!).

Fig. 4 r-y

Subarbusto $30-50 \mathrm{~cm}$ alt., ascendente ou decumbente. Caules subtetrágonos, glabros castanhos quando secos. Bainha estipular 2,5-3 mm compr., glabra, com 3-4 setas 1,5-2 mm compr. Folhas pseudoverticiladas pela presença de braquiblastos nas axilas, sésseis; lâminas 10-40×3-13 mm, estreitoelípticas ou elípticas, às vezes levemente falcadas, cartáceas, agudas no ápice, atenuadas ou cuneadas na base, glabras em ambas as faces, margens levemente recurvadas, glabras; nervuras secundárias 2-3 pares, inconspícuas na face superior, a nervura principal impressa na face superior, proeminente na inferior. Ramos florais com um glomérulo terminal, ou seguido por um glomérulo axilar, 8-15 mm diâm., densifloro, subtendidos por 2-4 brácteas foliáceas, patentes. Flores subsésseis, pedicelos ca. 0,3-0,4 mm compr. Hipanto turbinado, pubérulo. Cálice com pares de lobos desiguais, os maiores 1,2-2 mm compr., lanceolados, carenados, ciliados, os menores, 0,5$0,8 \mathrm{~mm}$ compr., estreito-triangulares, acuminados, ciliados; tubo do cálice desenvolvido no fruto, 11,2 mm compr. Corola 4-5,5 mm compr.; tubo 3$4 \mathrm{~mm}$ compr., hipocrateriforme, externamente glabro, com anel de tricomas moniliformes no terço inferior interno; lobos 1-1,5 mm compr., ovados, externamente pubérulo-papilosos, finamente pilosos na face interna. Estames subsésseis, inseridos na fauce da corola; filetes ca. 0,2 mm compr.; anteras ca. $1 \times 0,3-$ 0,4 mm, subelípticas, subinclusas. Estilete 4-4,5 mm compr., filiforme; lobos estigmáticos ca. 0,5 mm compr. Cápsulas 1,5-1,8 mm compr., obcônicas, pubérulas ou glabras na porção superior, pedúnculo ca. $0,5-0,8 \mathrm{~mm}$ compr. Sementes $0,8-1,2 \times 0,5-0,6 \mathrm{~mm}$, oblongóides, castanhas a castanho-escuras; face dorsal sem depressões, exotesta finamente reticulada; face ventral com encaixe retangular profundamente impresso, expandido nos ângulos. Material selecionado: BRASIL. BAHIA: Ituberá, 1342'27'S, 3900'53'W, 21.VI.2005, fl. e fr., J.G. Jardim et al. 4642 (HUEFS). ESPÍRITO SANTO: Guarapari, ES-060 entre Setiba-Guarapari, 26.V.1987, fl. e fr., O.J. Pereira et al. 906 (SP). RIO DE JANEIRO: Rio de Janeiro, Pedra da Gávea, 13.I.1963, fl. e fr., J.P.P. Carauta 166 (K, RB); Restinga de Itapeba, 13.XII.1962, fl., S. Ferreira 9 (K). Saquarema, REE de Jacarepiá, 14.VIII.1995, fl., $A$. Lobão et al. 6 A (RB).

Mitracarpus lhotzkyanus apresenta folhas pseudoverticiladas, glabras em ambas as faces, glomérulos terminais, densifloros, tubo da corola superando os maiores lobos do cálice e sementes com encaixe ventral retangular. O padrão de escultura das sementes relaciona esta espécie com M. megapotamicus. Entretanto, M. lhotzkyanus se distingue por ser uma planta mais robusta e glabra nos caules e nas folhas, pelas folhas de margens não ciliadas e pela corola sem papilas na face externa. Esta espécie ocorre ao longo do litoral, desde o sul da Bahia até o Rio de Janeiro. Espécie heliófita, comum em áreas de restinga, desenvolvendo-se sobre solos arenosos profundos ou sobre solos recém-formados em afloramentos rochosos. Quanto a seu status de conservação, a espécie é considerada quase ameaçada [NT].

13. Mitracarpus longicalyx E.B. Souza \& M.F. Sales, Brittonia 53: 482.2001 (2002). Tipo: BRASIL. CEARÁ: Aiuaba, Distrito Lagoa da Boiada, Sítio Vale do Boi, 6³4'S, 40¹7'W, 500 m, 5.IV.2000, fl., E.B. Souza et al. 508 (holótipo EAC!; isótipo CTES!, IPA!, K!, MO, NY, PEUFR!, UB!, US).

Fig. 5 a-i

Erva $30-40 \mathrm{~cm}$ alt., ereta, ascendente ou decumbente. Caules tetrágonos a subtetrágonos, geralmente com ramificações opostas, densamente pubescentes na região estipular e ao longo das margens, vilosos nas faces, com tricomas curtos, antrorsos. Bainha estipular 3-4 mm compr., pubescente, com 5-9 setas, 2-3 mm compr., glabras. Folhas opostas, sem braquiblastos nas axilas, sésseis; lâminas 23-28×5-9 mm, elípticas ou estreito-elípticas, cartáceas, agudo-mucronadas no ápice, atenuadas na base, margens basalmente pubescentes, ciliado- 
escabras em direção ao ápice, densamente escabras ou estrigosas na face superior, glabras sobre a superfície e com tricomas ao longo nas nervuras ou densamente pubescentes sobre toda a superfície na face inferior; nervuras secundárias 3-4 pares. Ramos florais com 1-3(-5) glomérulos terminais e axilares; glomérulos terminais, 9-12 mm diâm., subglobosos, densifloros, os axilares 6-9 cm diâm., subtendidos por 2-4(raramente 6-8) brácteas foliáceas, geralmente púrpuras na base. Flores pediceladas, pedicelos ca. $1 \mathrm{~mm}$ compr. Hipanto turbinado, glabro. Cálice com pares de lobos desiguais, os maiores, 2-3 mm compr., lanceolados, ciliados, os menores, $1-1,5 \mathrm{~mm}$ compr.estreitotriangulares, branco-hialinos, ciliados. Corola 3-5 mm compr., hipocrateriforme; tubo 2-3,5 mm compr., externamente glabro ou finamente pubérulo na porção superior, com anel de tricomas moniliformes na metade inferior interna; lobos 1-1,5 mm compr., ovado-triangulares. Estames sésseis, inseridos na fauce da corola; filetes ca. 0,3-0,4 mm compr.; anteras ca. 0,8-1 $\times 0,4 \mathrm{~mm}$, subelípticas, amarelas, subinclusas. Estilete 3,5-4(-5) mm compr., filiforme, ramos estigmáticos $0,8-1 \mathrm{~mm}$ compr. Cápsulas 1,5-2,2× 1-1,2 mm, obovóides, glabras, pedúnculo ca. $1 \mathrm{~mm}$ compr. Sementes $0,8-1 \times 0,5-0,6 \mathrm{~mm}$, obovóides; face dorsal com depressões semicirculares apicais, formadas a partir dos prolongamentos da depressão ventral, exotesta reticulada; face ventral com encaixe em forma de " $\mathrm{X}$ ".

Material selecionado: BRASIL. BAHIA: Feira de Santana, Campus UEFS, 30.VIII.1995, fl. e fr., L.P. Queiroz 4440 (HUEFS); $12^{\circ} 15^{\prime}$ 'S, 38 58'06”'W, 26.VI.1982, fl. e fr., C.M.B. Lobo 19 (HUEFS). CEARÁ: Aiuaba, Distr. Barra, 6.IV.2000, fl., E.B. Souza et al. 514 (EAC, IPA, $\mathrm{K}, \mathrm{UB}, \mathrm{HUVA}$ ). PERNAMBUCO: Petrolina, CPATSA, 25.VII.1984, fl. e fr., G.C.P. Pinto 134 (HBR, MG). PIAUÍ: Itaueira, 21.III.1984, fl. e fr., R.P. Orlandi 590 (MG).

Mitracarpus longicalyx caracteriza-se pelas brácteas involucrais frequentemente púrpuras na base, tubo do cálice desenvolvido no fruto $(1 \times 1,5 \mathrm{~mm}$ compr.) e pelas sementes com depressões dorsais semicirculares nos ângulos superiores. Esta espécie apresenta exotesta reticulada com o mesmo padrão de escultura encontrado em $M$. albomarginatus e M. nitidus. Apresenta distribuição geográfica restrita à região do semi-árido do Brasil, havendo registros para os estados do Piauí, Ceará, Pernambuco e Bahia. Esta espécie ocorre sob a forma de planta anual em áreas de caatinga, formando pequenas populações no estrato herbáceo sazonal. Ocorre preferencialmente em solos ácidos de saturação com sódio, de baixa fertilidade, com textura arenosa. O habitat tem baixa precipitação sazonal e está sujeito a forte ação antrópica, particularmente causada pela pastagem extensiva e pelas queimadas (Souza \& Sales 2001 [2002]). Quanto ao status de conservação essa espécie é considerada como não ameaçada [NE].

14. Mitracarpus megapotamicus (Spreng.) O. Kuntze, Revis. Gen. Plant. 3(2): 121. 1898. Spermacoce megapotamica Spreng., Syst. Veg. 4(2): Cur. Post. 40. 1827. Tipo: BRASIL. "Rio Grande", s.d., fl. e fr., J. Sellow s.n. (holótipo B†; duplicatas não localizadas).

Fig. 5 j-p

Mitracarpus sellowianus Cham. \& Schltdl., Linnaea 3: 361. 1828. Tipo: BRASIL. "Brasilia meridionalis", s.d., J. Sellow s.n. (holótipo B†; lectótipo $\mathrm{G}$ ! aqui designado).

Mitracarpus cuspidatus DC., Prodr. 4: 572. 1830. Tipo: URUGUAI. Montevideo, s.d., Sellow s.n. (holótipo G!). ("Mitracarpum cuspidatum”).

Mitracarpus peladilla Griseb., Abh. Königl. Ges. Wiss. Göttingen 24: 158. 1879. Tipo: ARGENTINA. Palmar Grande, s.d.,s.c. (GOET).

Mitracarpum selloanus var. latifolius $\mathrm{f}$. latifolius Chodat \& Hassl., Bull. Herb. Boissier, Ser. 2, 4: 190. 1904. Tipo: PARAGUAI. Prope Chocolo, XII., fl. e fr., E. Hassler 6611 (holótipo G!; isótipo $\mathrm{BM}$ !, K!, P!, W!).

Mitracarpum selloanus var. latifolius f. robustus Chodat \& Hassl., Bull. Herb. Boissier, Ser. 2, 4: 190. 1904. Tipo: PARAGUAI. Prope Concepción, IX, fl., E. Hassler 7520 (holótipo G!; isótipo BM!, K!, P!, W!). Mitracarpum selloanus var. latifolius f. tenellus Chodat \& Hassl., Bull. Herb. Boissier, Ser. 2, 4: 190. 1904. Tipo: PARAGUAI. Prope San Estanislao, VIII, fl., E. Hassler 4272 (holótipo G!; isótipo BM!, K!). Mitracarpus felipponei Beauverd, Bull. Soc. Bot. Genève, Ser. 2, 12: 15.1920(1921). Tipo:URUGUAI. Montevidéo, Malvin, prope Montevidéo, V.1919, fl. e fr., F. Felippone 3229 (holótipo G!).

Mitracarpus megapotamicus (Spreng.) Standl., Publ. Field Mus. Nat. Hist. Bot. 7: 33. 1931. Spermacoce megapotamica Spreng., Syst. Veg. 4(2): Cur. Post. 40. 1827. Tipo: BRASIL. "Rio Grande”, s.d., fl. e fr., J. Sellow s.n. (holótipo B†; duplicatas não localizadas).

Erva ou subarbusto (7-)10-30(-50) cm alt., ereto ou decumbente. Caules tetrágonos nas porções superiores, cilíndricos na base, vináceos, pubérulos, híspido-vilosos ou glabrescentes. Bainha estipular 23,5 mm compr., pubérula, com (3-)7-9(-13) setas 2$7 \mathrm{~mm}$ compr., glabras até densamente ciliadas. Folhas pseudoverticiladas pela presença de braquiblastos nas axilas, sésseis ou pseudopecioladas; lâminas (9-) 


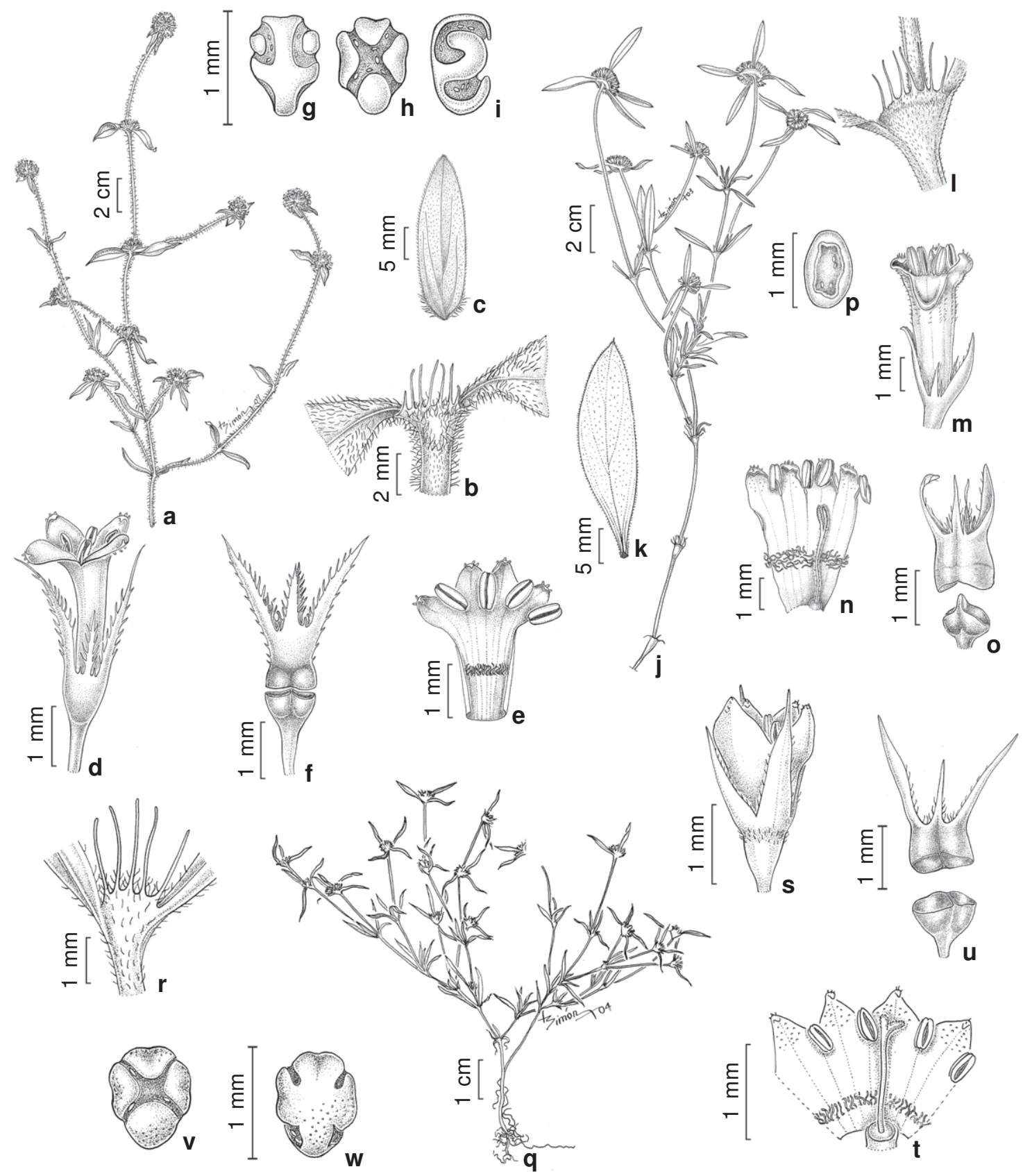

Figura 5 - a-i. Mitracarpus longicalyx - a. ramo floral; b. bainha estipular; c. folha; d. flor; e. corola aberta; f. cápsula aberta. g-i. semente; g. face dorsal; h. face ventral; i. face lateral; j-p. M. megapotamicus - j. ramo floral; k. folha; 1. bainha estipular; m. flor; n. corola aberta; o. cápsula aberta; p. semente, face ventral. q-w. M. microspermus - q. hábito; r. bainha estipular; s. flor; t. corola aberta; u. cápsula aberta; v. semente, face ventral; w. semente, face dorsal. (a Queiroz et al. 4440; b Souza et al. 508; c-i Lobo 19; j-p Krapovickas \& Cristóbal 44397; q Hatschbach \& Kummrow 38519; r Silva et al. 4078; s-w Hatschbach \& Kummrow 38519).

Figure 5 - a-i. Mitracarpus longicalyx - a. flowering branch; b. stipular sheath; c. leaf; d. flower; e. open corolla; f. open fruit. g-i. seed; g. dorsal view; h. ventral view; i. lateral view. j-p. M. megapotamicus - j. flowering branch; k. leaf; 1. stipular sheath; m. flower; n. open corolla; o. open fruit; p. seed, ventral view. q-w. M. microspermus - q. habit; r. stipular sheath; s. flower; t. open corolla; u. open fruit; v. seed, ventral view; w. seed, dorsal view. (a Queiroz et al. 4440; b Souza et al. 508; c-i Lobo 19; j-p Krapovickas \& Cristóbal 44397; q Hatschbach \& Kummrow 38519; r Silva et al. 4078; s-w Hatschbach \& Kummrow 38519). 
15-30(-70) ×(2-)5-12(-24) mm, (estreito-)elípticas, ou lineares, agudas, acuminadas ou acuminadomucronadas no ápice, atenuadas na base, cartáceas, ciliadas a ciliado-escabras nas margens, face superior escabra, estrigosa ou hirta, face inferior esparsamente escabra, densamente estrigosa ou pubérula; nervuras secundárias 3-5 pares, não evidentes ou conspícuas na face inferior. Ramos florais geralmente com um glomérulo terminal, ou seguido por 1-2 glomérulos axilares; glomérulos (7-) 10-20 mm diâm., globosos, densifloros, subtendidos por 2-4 brácteas foliáceas. Flores pediceladas, pedicelos ca. 0,5 mm compr. Hipanto turbinado, glabro ou levemente pubérulo. Cálice com pares de lobos desiguais, os maiores 2-2,5 mm compr., lanceolados, ciliados, os menores $0,6-1 \mathrm{~mm}$ compr., estreito-triangulares, basalmente ciliados. Corola (3,5-)5-8 mm compr., hipocrateriforme; tubo 2-6 mm compr., pubérulo-papiloso a papiloso na porção apical externa, com anel de tricomas moniliformes na metade inferior interna; lobos ca. $1 \mathrm{~mm}$, ovadotriangulares, papilosos externamente, pubérulopapilosos internamente. Estames subsésseis, inseridos na fauce da corola; filetes ca. $0,5 \mathrm{~mm}$ compr.; anteras ca. 0,6-1 ×0,4 mm compr., subelípticas, subinclusas. Estilete $4-8 \mathrm{~mm}$ compr., filiforme; ramos estigmáticos ca. $0,5 \mathrm{~mm}$ compr. Cápsulas $(0,8-) 1,2-3 \times(0,6-) 1-2,5$ mm, obovóides, glabras ou levemente pubérula na porção superior, pedúnculo ca. 0,5 mm compr. Sementes $0,8-2 \times 0,6-$ 1,5 mm, oblongóides, obovóides ou subglobosas, castanhas a castanho-escuras; face dorsal sem depressões, exotesta suavemente reticulada; face ventral com encaixe retangular ou quadrangular profundamente impresso.

Material selecionado: BRASIL. MATO GROSSO DO SUL: Corumbá, Serra do Urucum, 15.III.1972, fl. e fr., G. Hatschbach 29525 (MBM). RIO GRANDE DO SUL: Porto Alegre, Morro das Abertas, 14.VIII.1979, fl., e fr., J.E.A. Mariath 737 (HAS).

Material adicional examinado: PARAGUAI: BOQUERÓN: 24 km SE Mariscal Estigarribia, 12.XII.1992, fl. e fr., $A$. Krapovickas \& C.L. Cristóbal 44397 (G).

Mitracarpus megapotamicus é uma espécie altamente variável fenotipicamente, apresentando muitas variações intra e interpopulacionais ao longo de sua faixa de distribuição. Porto et al. (1977) verificaram esta variação ao mencionar que $M$. megapotamicus apresenta ampla variação na intensidade e no tamanho dos tricomas no fruto e nos lobos do cálice. Esta espécie apresenta hábito decumbente, com folhas pseudoverticiladas, glomérulos apicais densifloros, tubo da corola superando os maiores lobos do cálice e sementes sem depressões dorsais, com encaixe ventral quadrangular ou retangular. Caracteres como caules e folhas densamente pilosos, glomérulos apicais, corola pilosa externamente e sementes com encaixe ventral quadrangular ou retangular, relacionam $M$. megapotamicus com $M$. hasslerianus, uma espécie endêmica do Paraguai. Entretanto, M. hasslerianus é uma planta mais robusta, ereta ou apoiante, até $1 \mathrm{~m}$ alt., com caules fortemente tetrágonos e levemente alados, lobos menores do cálice partidos e sementes sublenticulares. Analisando as coleções do herbário de Genebra, não foi possível localizar duplicatas de Sellow s.n. correspondentes ao tipo de Spermacoce megapotamica, contudo foi encontrado um isótipo de $M$. sellowianus. A coleção se apresenta em bom estado de conservação e possui flores e frutos, o que motivou sua escolha como lectótipo de $M$. sellowianus (CINB, Art. 9.10). Espécie com distribuição geográfica no Brasil, Bolívia, Paraguai, Argentina e Uruguai. No Brasil, ocorre nos estados do Mato Grosso do Sul e Rio Grande do Sul. Espécie heliófita, seletiva xerófita, habitando campos arenosos ou pedregosos. Quanto ao status de conservação, essa espécie é considerada como não ameaçada [NE].

15. Mitracarpus microspermus K. Schum., Martius, Eichler \& Urban, Fl. bras. 6(6): 83. 1888. Tipo: BRASIL. "In Guiana Anglica ad fluvium Rio Branco" Rio Branco, 1840, fl. e fr., R. Schomburgk 856 pro parte (holótipo $\mathrm{B} \dagger$; lectótipo BM!, aqui designado). Fig. 5 q-w Mitracarpus minutiflorus K. Schum., Fl. bras. 6(6): 80. 1888. Tipo: BRASIL. GOIÁS: “inter urbem Goiaz et Cavalcante”, W.J. Burchell 7820 (holótipo $\mathrm{B} †$; lectótipo BR!, aqui designado; isolectótipo $\mathrm{K}$ !), syn. nov.

Erva 2,5-10 $\mathrm{cm}$ alt., cespitosa, prostrada, ascendente ou ereta. Caules cilíndricos, delgados, pubérulos ou glabros, com tricomas adpressos voltados para cima. Bainha estipular ca. $1 \mathrm{~mm}$ compr., com superfície glabra, somente com longos tricomas na área de inserção das setas, com 3-5 setas, 1-2 mm compr., glabras. Folhas pseudoverticiladas pela presença de braquiblastos nas axilas, sésseis; lâminas 6-12×0,5-1 $\mathrm{mm}$, lineares, apiculadas no ápice, atenuadas na base, cartáceo-rígidas, esparsamente escabras ou glabras na face superior, glabras na face inferior, margens espessadas, glabras ou ciliadas, recurvadas ou revolutas; nervuras secundárias inconspícuas. Ramos florais com 1-3 glomérulos terminais; glomérulos 3$5 \mathrm{~mm}$ diâm., globosos, paucifloros, subtendidos por 4-8 brácteas foliáceas. Flores subsésseis; pedicelos 
ca. 0,5 mm compr. Hipanto obcônico, glabro ou levemente pubérulo no ápice. Cálice com pares de lobos desiguais, os maiores 1,5-2 mm compr., linearlanceolados, marginados, ciliados na base, os menores 1mm compr., lineares, hialinos, ciliados na base. Corola 1,2-1,8 mm compr., tubo 1-1,2 mm compr., externamente glabro; lobos ca. 0,5-0,6 mm compr., ovados, papilosos no ápice, com anel ralo de tricomas moniliformes na metade inferior interna. Estames sésseis; anteras ca. 0,4 × 0,2 mm compr., oblongas, subinclusas. Estilete 1-1,2 mm compr., filiforme; ramos estigmáticos ca. $0,3 \mathrm{~mm}$ compr. Cápsulas 1,2-1,5 mm compr., obovóides, glabras. Sementes ca. 0,8 $\times 0,6 \mathrm{~mm}$, obovóides; face dorsal com depressão cruciforme conspícua ou suavemente impressa, exotesta fovéolo-reticulada; face ventral com encaixe em forma de "X".

Material selecionado: BRASIL. BAHIA: Riachão das Neves, 1346'49"S, 4454'39'W, 6.IV.2005, fl. e fr., J.G. Carvalho-Sobrinho et al. 410 (HUEFS). DISTRITO FEDERAL: Guará, 18.III.1968, fl. e fr., H.S. Irwin et al. 21398 (K). GOIÁS: Cavalcante, 10.III.1969, fl. e fr., H.S. Irwin et al. 24229 (K). MINAS GERAIS: Pirapora, 13.III.1996, fl. e fr., G. Hatschbach et al. 64614 (MBM). PARÁ: Curuá, Serra do Flexal, IX.1927, fl., A. Lutzelburg 21169 (R). RORAIMA: On an Azimuth 4905' Boa Vista, at $50 \mathrm{~km}$ (BR 401), Faz. Quixabeira, 13.X.1977, fl. e fr., L. Coradin \& M. R. Cordeiro 642 (INPA). TOCANTINS: Mun. Gurupi, 30.III.1976, fl. e fr., G. Hatschbach \& R. Kummrow 38519 (MBM). Mun. Lagoa da Confusão, Parque Nacional do Araguaia, Reserva Indígena Carajá - Macaúba, Lajedo, $10^{\circ} 25^{\prime} \mathrm{S}, 50^{\circ} 28^{\prime} \mathrm{W}$, 23.III.1999, fl. e fr., M.A. Silva et al. 4078 (IBGE).

Mitracarpus microspermus distingue-se através do hábito cespitoso, caules cilíndricos, delgados, folhas pseudoverticiladas de margens espessadas, lobos do cálice basalmente ciliados, tubo da corola menor do que os maiores lobos do cálice e sementes com depressão cruciforme dorsal, conspícua ou suavemente impressa. Esta espécie tem afinidade com $M$. parvulus, da qual se diferencia por apresentar caules glabros ou pubérulos (vs. densamente pilosos), com folhas pseudoverticiladas, glabras ou esparsamente escabras e espessadas nas margens (vs. opostas, híspidas em ambas as faces, sem espessamento nas margens), hipanto glabro ( $v s$. pubérulo) no ápice e pelas sementes com ( $v s$. sem) depressão cruciforme dorsal. A coleção Schomburgk 856 exibe na etiqueta a expressão "In Guiana Anglica ad fluvium Rio Branco" que, segundo autores como Andersson (1992), corresponde a uma área dentro do território brasileiro no estado de Roraima, próxima à fronteira com o Guiana Inglesa. Na ocasião, materiais pertencentes a duas espécies receberam um mesmo número de coletor, o que levou Schumann (1888) a reconhecer parte da coleção como uma espécie distinta, fazendo a publicação de $M$. microspermus. A outra parte da coleção, com corolas maiores, foi separada como material tipo de M. scabrellus. Devido ao desaparecimento do material original estudado por Schumann (1888) em Berlim, e por apresentar bom estado de conservação, portando frutos e sementes, a coleção Schomburgk 856 pro parte, do Herbário BM, foi escolhida como lectótipo de M. microspermus. Por outro lado, a coleção Burchell 7820, do Herbário BR, foi identificada pelo próprio Schumann como M. minutiflorus. Este binômio aparece na chave de identificação do seu tratamento de Mitracarpus para a Flora brasiliensis, contudo, por razões ainda desconhecidas, a descrição da espécie não consta no texto daquela publicação. A análise da coleção Burchell 7820 indica que se trata de um exemplar de $M$. microspermus, uma vez que os caracteres das folhas, flores e sementes correspondem à descrição desta última. Com base nessas observações, é feita a sinonimização de $M$. minutiflorus sob $M$. microspermus. Pelas mesmas razões apontadas para o material original de $M$. microspermus, a coleção Burchell 7820, do acervo do herbário BR, é aqui tomada como lectótipo de $M$. minutiflorus $\mathrm{K}$. Schum. Esta espécie tem distribuição geográfica registrada para o Brasil, Guiana e Suriname. No Brasil, é reportado para os estados de Roraima, Pará, Tocantins, Goiás, Mato Grosso e Minas Gerais. Quanto ao status de conservação, essa espécie é considerada como não ameaçada [NE].

16. Mitracarpus nitidus E.B. Souza \& Zappi, sp. nov. Tipo: BRASIL. BAHIA: Morro do Chapéu, Tabuleiro dos Tigres, Estrada Morro do ChapéuBonito, ca. $5 \mathrm{~km}$ da sede municipal, 11³6'04'S, 4109'47'W, 1093 m, 17.VI.2004, fl. e fr., E.B. Souza \& C.O.C. Ramos 912 (holótipo HUEFS; Isótipo CTES, HUVA, K, NY).

Fig. 6 a-j

Mitracarpus hirto similis, sed calycis lobis ad basem ciliatis (nec ad marginem tota), corolla 3,5-4 mm longa, quam calycis lobis longiore, extus glabra (vs. corolla 1,2-3 mm longa quam calycis lobis aequanti vel breviore, extus puberulopapillosa), capsullae parti superiore glabra (nec pilosa), et seminibus cum lobo basale angusto et depressionis ventralis projecturis apicalibus brevibus (vs. seminibus cum lobo basale lato et depressionis ventralis projecturis apicalibus longo) differt. 
Subarbusto $15-30 \mathrm{~cm}$ alt., ascendente, basalmente lenhoso. Caules cilíndricos na base, tetrágonos nas porções superiores, esfoliantes, glabros ou levemente pubérulos na região estipular. Bainha estipular 2-2,5 mm compr., glabra, somente com tricomas esparsos na margem, com 5-6 setas 2-4 mm compr., glabras. Folhas pseudoverticiladas pela presença de braquiblastos nas axilas, sésseis; lâminas 17-45 × 3-9 mm, linear-lanceoladas, lanceoladas ou ovadas, herbáceas, acuminadas no ápice, atenuadas na base, brilhantes na face superior, glabras em ambas as faces, margens revolutas, glabras ou esparsas a densamente escabras, nervura principal impressa acima, proeminente abaixo; nervuras secundárias 2-3 pares, ou inconspícuas. Ramos florais com 1-3 glomérulos terminais e axilares; glomérulos 10-17 mm diâm., globosos, subtendidos por 2-4 brácteas foliáceas. Flores subsésseis; pedicelos ca. 0,5 mm compr. Hipanto obcônico, glabro. Cálice com pares de lobos desiguais, virgados, os maiores 2-2,5 mm compr., estreitolanceolados, longamente acuminados, glabros, os menores 1-1,5 mm compr., estreito-triangulares, acuminados, glabros. Corola 3,5-4 mm compr., (sub)infundibuliforme; tubo 2,5-3,5 mm compr., glabro externamente, com anel de tricomas moniliformes próximo do centro do tubo internamente; lobos ca. $1 \mathrm{~mm}$ compr., ovados, glabros, levemente papilosos no ápice. Estames subsésseis, inseridos na fauce da corola, anteras ca. $0,8 \times 0,4 \mathrm{~mm}$, oblongas, subinclusas. Estilete ca. $4 \mathrm{~mm}$ compr., filiforme. Cápsulas 1-1,2 mm compr., obcônicas, glabras. Sementes ca. 0,6-0,8 ×0,4 mm, oblongóides, castanho-claras, exotesta fovéolo-reticulada; face dorsal sem depressões; face ventral com encaixe em forma de "X".

Material selecionado: BRASIL. BAHIA: Morro do

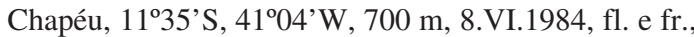
E.F. Almeida \& M.C. Ferreira 310 (ALCB, CEPEC, HBR, RB); $11^{\circ} 35^{\prime} \mathrm{S}, 41^{\circ} 12^{\prime} \mathrm{W}, 1000 \mathrm{~m}, 30 . \mathrm{V} .1980$, fl., R.M. Harley et al. 22756 (CEPEC, CTES, K); BA-052 em direção a Utinga, 30.VIII.1990, fl. e fr., J.L. Hage et al. 2310 (CEPEC, CTES); Tabuleiro dos Tigres,

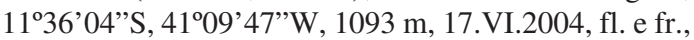
E.B. Souza \& C.O.C. Ramos 917, 921 (HUEFS); Estrada

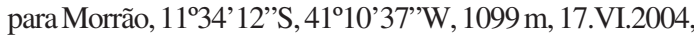
fl. e fr., E.B. Souza \& C.O.C. Ramos 929 (HUEFS). Serra

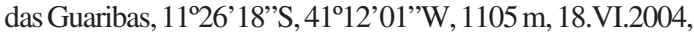
fl. e fr., E.B. Souza et al. 933, 936 (HUEFS).

Mitracarpus nitidus apresenta-se mais relacionado com $M$. hirtus, especialmente pelo hábito ascendente e pela morfologia e escultura das sementes. Entretanto, ambas as espécies podem ser separadas pelo exame das flores, frutos e sementes: lobos do cálice basalmente ciliados, corola 3,5-4 mm compr., com tubo superando os maiores lobos do cálice, glabra externamente, porção superior da cápsula glabra e sementes com o lobo basal estreito e prolongamentos apicais do encaixe ventral curtos em $M$. nitidus; e lobos do cálice com margems completamente ciliadas, corola 1,2-3 mm compr., com tubo menor ou aproximadamente do tamanho dos maiores lobos do cálice, pubérulopapilosa externamente, porção superior da cápsula pilosa e sementes com lobo basal amplo e prolongamentos apicais do encaixe ventral longos em $M$. hirtus. Espécie somente conhecida de Morro do Chapéu, Bahia. Habita áreas acima de 900 m de altitude, em relevos tabulares com solos arenosos profundos. Populações desta espécie são simpátricas com as de $M$. rigidifolius Standl. O epíteto se refere às folhas com face superior brilhante quando em estado natural. Quanto ao status de conservação essa espécie é considerada como vulnerável [VU D2]. A pequena área de ocorrência desta espécie está ameaçada pela remoção de areia para construção civil e pelo acúmulo de lixo lançado de forma desordenada.

17. Mitracarpus parvulus K. Schum., in Martius, Eichler \& Urban, Fl. bras. 6(6): 84. 1888. Tipo: BRASIL. TOCANTINS: "ad Porto Real" [hoje Porto Nacional], s.d., W.J. Burchell 8674 (holótipo B†; lectótipo BR!, aqui designado; isolectótipo K!, P!).

Fig. 6k-p

Erva 5-10 cm alt., cespitosa, ascendente ou decumbente. Caules cilíndricos, estreitos, púrpuraescuros, com tricomas longos, híspidos, entrepostos com tricomas curtos, adpressos, vilosos, densamente distribuídos. Bainha estipular 1-1,2 mm compr., híspida, com 5-7 setas, 1-2 mm compr. Folhas opostas sem braquiblastos nas axilas; lâminas 7-15 × 1-4 mm, estreito-elípticas ou lineares, agudo-mucronadas no ápice, atenuadas na base, cartáceas, ciliadoaculeadas nas margens, híspidas em ambas as faces ou híspidas na face superior, glabras na superfície inferior, somente com tricomas ao longo da nervura principal; nervuras secundárias inconspícuas. Ramos florais geralmente com 2 glomérulos, ou portando somente um glomérulo terminal; glomérulos 4-6 mm diâm., globosos, o terminal subtendido por 4 brácteas foliáceas, em pares desiguais, o axilar subtendido por 2 brácteas foliáceas. Flores subsésseis; pedicelos ca. 0,5 mm compr. Hipanto obcônico, levemente pubérulo na porção superior. Cálice com pares de lobos desiguais, os maiores 2-2,2 mm compr., carenados, apiculados, ciliados, os menores 


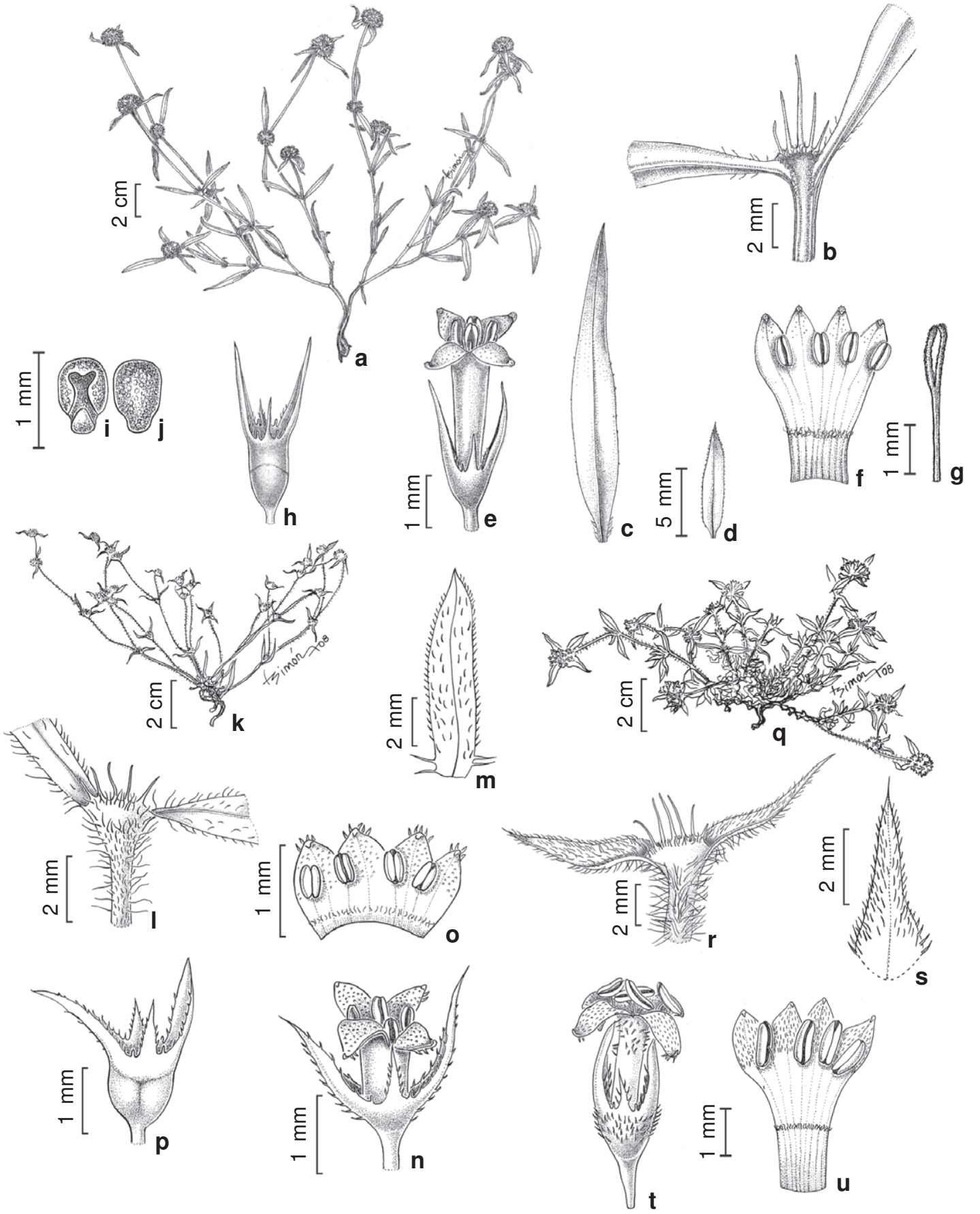

Figura 6 -a-j. Mitracarpus nitidus - a. hábito; b. bainha estipular; c-d. folhas; e. flor; f. corola aberta; g. estilete; h. cápsula imatura; i. semente, face dorsal; j. semente, face ventral. k-p. M. parvulus - k. hábito; 1. bainha estipular; m. folha; n. flor; o. corola aberta; p. cápsula imatura. q-u. M. pusillus - q. hábito. r. bainha estipular; s. folha; t. flor; u. corola aberta. (a-j Souza \& Ramos 912; k Eiten \& Eiten 3573; 1-p Burchell 8674; q Souza et al. 1053; r-u Pirani et al. 5310). Figure 6 - a-j. Mitracarpus nitidus - a. habit; b. stipular sheath; c-d. leaves; e. flower; f. open corolla; g. style; h. young fruit; i. seed, dorsal view; j. seed, ventral view. k-p. M. parvulus - k. habit; 1. stipular sheath; m. leaf; n. flower; o. open corolla; p. young fruit. q-u. M. pusillus - q. habit; r. stipular sheath; s. leaf; t. flower; u. open corolla. (a-j Souza \& Ramos 912; k Eiten \& Eiten 3573; 1-p Burchell 8674; q Souza et al. 1053; r-u Pirani et al. 5310). 
1-1,5 mm compr., (estreito-)triangulares, ciliados. Corola 1-1,2 mm compr., hipocrateriforme; tubo 0,5$0,6 \mathrm{~mm}$ compr., externamente glabro, com anel esparso de tricomas moniliformes na metade inferior interna; lobos ca. 0,5 mm compr., ovados, com tricomas papilosos no ápice, internamente finamente pubérulos. Estames sésseis; anteras ca. 0,3-0,5 × ca. 0,2 mm., oblongas, subinclusas. Estilete 1-1,5 mm compr., ramos estigmáticos ca. $0,5 \mathrm{~mm}$ compr. Cápsulas 1,2-2×1,2-1,5 mm, obovóides, pubérulas na porção superior, pedúnculo ca. $0,5 \mathrm{~mm}$ compr. Sementes 0,6-0,9 x ca. 0,5 mm, obovóides, castanhas, exotesta reticulada; face dorsal sem depressões; face ventral com encaixe em forma de "X".

Material selecionado: BRASIL. MATO GROSSO: Xavantina, km 280 Xavantina-Cachimbo road, 23.III.1968, fl. e fr., D. Philcox \& A. Ferreira 4621 (K). MINAS GERAIS: 1845, fl. e fr., J. Widgren s.n. (R 150742). PARÁ: Marabá, 4.IV.1974, fl. e fr., G.S. Pinheiro \& J.F.V. Carvalho 69 (RB). TOCANTINS: Aliança do Tocantins, $11^{\circ} 02^{\prime} \mathrm{S}, 48^{\circ} 43^{\prime} \mathrm{W}$, 22.IV.1980, fl. e fr., E. Mileski 320 (HBR); Porto Nacional, 11.III.1962, fl., G. Eiten \& L.T. Eiten 3573 (SP).

Mitracarpus parvulus caracteriza-se por seus caules cobertos por tricomas menores, adpressos, entrepostos com tricomas longos híspidos, folhas híspidas, tubo da corola menor do que os maiores lobos do cálice e sementes sem depressões dorsais. Mitracarpus parvulus apresenta afinidade com $M$. microspermus e com M. eritrichoides. Entretanto, M. parvullus distingue-se de M. microspermus por suas folhas opostas ( $v s$. pseudoverticiladas em $M$. microspermus), sem margens espessadas, densamente pilosas sobre as lâminas, e pela bainha estipular com 5-7 setas (vs. 3-5). Por outro lado, distingue-se de M. eritrichoides por apresentar hábito ascendente ( $v s$. prostrado), com margens foliares sem espessamentos ( $v s$. espessadas) e corola menor, 1-1,2 mm compr. (vs. 2-2,4 mm). O exemplar Burchell 8674, depositado no acervo do Herbário BR, foi escolhido como lectotipo de M. parvulus por ser mais completo, apresentando flores e frutos. Espécie com distribuição no Brasil e na Venezuela. No Brasil, a espécie é reportada para os estados do Pará, Tocantins, Mato Grosso e Minas Gerais. Ocorre em áreas de Cerrado sobre solos argilosos. Quanto ao status de conservação, essa espécie é considerada como não ameaçada [NE].

18. Mitracarpus pusillus Steyerm., Brittonia 30: 36. 1978. Tipo: BRASIL. MINAS GERAIS: wet campo, Serra do Cabral, summit ca. $8 \mathrm{~km}$ W of Joaquim Felício, 1200 m, 7.III.1970, fl., H.S. Irwin et al. 27120 (holótipo UB!; isótipo NY).

Fig. $6 \mathrm{q}-\mathrm{u}$

Erva de pequeno porte, decumbente ou prostrada, cespitosa ou formando almofadas. Caules
5-7 cm compr., com entrenós basais 1-4 mm compr., densamente cobertos pelas folhas, entrenós terminais até $40 \mathrm{~mm}$ compr., tetrágonos, marginados, densamente híspidos. Bainha estipular 1-1,2 mm compr., pubescentes, com 5-7 setas, 1-4 mm compr., glabras. Folhas pseudoverticiladas pela presença de braquiblastos nas axilas, sésseis; lâminas 5-22 × 1-10 mm, ovadas, lanceoladas ou linear-lanceoladas, acuminado-aristadas no ápice, subcordadas ou truncadas na base, cartáceo-rígidas, cinéreohíspidas em ambas as faces, ciliadas nas margens; nervuras secundárias inconspícuas Ramos florais geralmente com um glomérulo terminal, 5-15 mm diâm., subgloboso, congesto, subtendido por 6-8 brácteas involucrais, foliáceas. Flores pediceladas, pedicelos ca. $1 \mathrm{~mm}$ compr. Hipanto obcônico, pubescente. Cálice com pares de lobos desiguais, os maiores 2-2,8 mm, linear-lanceolados, carenados, aristados, ciliado-híspidos na metade inferior das margens, os menores 1-1,5 mm compr., triangularlanceolados, aristados, ciliado-híspidos na base. Corola 3-4,5 mm compr., hipocrateriforme; tubo 2$3 \mathrm{~mm}$ compr., pubérulo na metade superior externa, com anel de tricomas moniliformes na metade interna; lobos 1-1,5 mm compr., ovados, subagudoapiculados, papiloso-pubérulos externamente, finamente pubérulos internamente. Estames inseridos na fauce da corola; filetes ca. $0,3-0,5 \mathrm{~mm}$ compr.; anteras ca. 0,8-1×0,4 mm compr., oblongas, subinclusas. Estilete 3-3,5 mm compr.; ramos estigmáticos ca. 0,8 mm compr. Cápsulas ca. 1,2× $1 \mathrm{~mm}$, obcônicas, pubérulas no ápice. Sementes ca. $0,8 \times 0,5 \mathrm{~mm}$, obovóides ou globosas, castanhas; face dorsal sem depressão cruciforme, exotesta papilada; face ventral com encaixe em forma de "X". Material selecionado: BRASIL. MINAS GERAIS: Serra do Cabral, 17²41'57'S, 44¹6'15'W, 26.I.2004, fl., J.R.

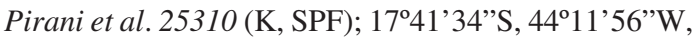
30.III.2005, fl., E.B. Souza et al. 1053 (HUEFS). Buenópolis, 28.IX.1949, fl. e fr., M. Magalhães 4560 (RB).

Mitracarpus pusillus caracteriza-se por seu porte herbáceo, prostrado ou decumbente, caules densamente híspidos, folhas coriáceas, rígidas, híspidas em ambas as faces, glomérulos subtendidos por 6-8 brácteas involucrais, e sementes com exotesta papilada. Mitracarpus pusillus é afim de M. steyermarkii, com a qual compartilha folhas (linear-)lanceoladas, rígidas, e sementes papiladas. Entretanto, M. pusillus se distingue de $M$. steyermarkii por apresentar hábito prostrado ou decumbente ( $v s$. hábito ereto), folhas sem espessamentos ( $v s$. folhas fortemente espessadas) e anteras subinclusas ( $v s$. anteras inclusas). É endêmica da Serra do Cabral, MG, ocorrendo em 
solos arenosos entre afloramentos rochosos, na vegetação de Campo Rupestre. Quanto ao status de conservação, essa espécie é considerada como vulnerável [VU D2], ocorrendo em apenas uma localidade com área de ocupação menor que $20 \mathrm{~km}^{2}$.

19. Mitracarpus recurvatus Standl., Publ. Field Mus., Bot. Ser. 8: 384. 1931. Tipo: BRASIL. MINAS GERAIS: Paracatu, "prés de porto", 1894, fl. e fr., A. Glaziou 21511 (holótipo K!; isótipo G!, P!). $\quad$ Fig. 7 a-g

Mitracarpus microphyllus Glaziou, Bull. Soc. Bot. France 56 (Mém. 3d): 364. 1909. Tipo: BRASIL. MINAS GERAIS: Paracatu, "prés de porto", 1894, fl. e fr., A. Glaziou 21511, nomen nudum.

Erva $6-10 \mathrm{~cm}$ alt., ereta ou ascendente, basalmente lenhosa, geralmente formando almofada. Caules de entrenós basais muito curtos, 1-5 mm compr., completamente encobertos pelas folhas, os terminais mais longos, até $23 \mathrm{~mm}$ compr., densamente híspidos. Bainha estipular 1-2 mm compr., pilosa, com 3-7 setas, 1-3 mm compr., rígidas, glabras. Folhas pseudoverticiladas pela presença de braquiblastos nas axilas, sésseis; lâminas 3-5 ×0,5-2 mm, lineares a linearlanceoladas, acuminado-apiculadas no ápice, estreito-atenuadas na base, coriáceo-rígidas, pungentes, recurvadas, híspidas em ambas as faces, margens espessadas, glabras; nervuras secundárias inconspícuas. Ramos florais com 1-2 glomérulos, ou somente com um glomérulo terminal; raramente em fascículos paucifloros, inseridos nas axilas das folhas superiores; glomérulos 6-14 mm diâm., globosos, densifloros. Flores subsésseis, pedicelos ca. 0,5 mm compr. Hipanto obovóide, densamente alvo-viloso. Cálice com pares de lobos desiguais, raramente subiguais, os maiores $2-3 \mathrm{~mm}$ compr., lanceolados, longo-acumindos, ciliados, brancos nas margens, os menores $1,5-2,8 \mathrm{~mm}$, estreitotriangulares, longo-acuminados, compr., ciliados. Corola 3,5-4,5 mm compr., hipocrateriforme; tubo 1,5-2 mm compr., esparsamente pubérulo-papilosa na metade superior externa, com anel de tricomas moniliformes no terço inferior interno, lobos 11,5 mm compr., ovados, finamente pubérulos internamente, papilosos no ápice. Estames subsésseis, inseridos na fauce, anteras ca. $0,8 \times 0,4 \mathrm{~mm}$ compr., oblongas, subinclusas. Estilete 2,5-3 mm compr., filiforme. Cápsulas 0,8-1 × 1-1,2 mm compr., obcônicas, hirtas na porção superior. Sementes ca. 0,6-0,8 ×0,5-0,6 mm, obovóides, face dorsal sem depressão cruciforme, exotesta papilada; face ventral com encaixe em forma de " $X$ ".
Material examinado: BRASIL. DISTRITO FEDERAL: Reserva Ecológica do IBGE, 20.IV.1982, fl. e fr., B.A.S. Pereira 238 (K, IBGE). GOIÁS: Alto Paraíso de Goiás, 1404'21''S, 47³0'00'W, 26.IV.1998, fl. C. Munhoz et al. 722 (UB); Chapada dos Veadeiros, 5-15 km S of Veadeiros to São João da Aliança, 21.VII.1964, fl., G.T. Prance \& N.T. Silva 58281 (U).

Mitracarpus recurvatus caracteriza-se por seu hábito ereto, folhas pseudoverticiladas, coriáceas, rígidas, pungentes, híspidas em ambas as faces e com margens espessadas e glabras, e sementes com exotesta papilada. Os caracteres das folhas e da escultura das sementes aproximam esta espécie de M. steyermarkii, da qual se distingue pela corola menor (3,5-4,5 mm compr. vs. 5-7 mm em M. steyermarkii) e pelos estames com anteras subinclusas (vs. anteras inclusas). A publicação do binômio $M$. microphyllus por Glaziou (1909) não foi acompanhada por uma descrição ou diagnose, nem por uma ilustração do material tipo, razão pela qual se considerou o mesmo um "nomen nudum", conforme a recomendação 50B do CINB. Espécie com distribuição geográfica em Goiás, Minas Gerais e Distrito Federal. Habita o campo limpo, sobre solos arenosos úmidos, em vegetação de Cerrado. Quanto ao status de conservação, essa espécie é considerada como quase ameaçada [NT], apesar de ocorrer em uma área restrita, todas as populações conhecidas encontram-se sob proteção em unidade de conservação.

20. Mitracarpus rigidifolius Standl., Publ. Field Mus. Nat. Hist., Bot. Ser. 8: 384. 1931. Tipo: BRASIL. BAHIA: Serra do São Ignácio, II.1907, fl. e fr. E. Ule 7559 (holótipo K!).

Fig. 7 h-p

Subarbusto 30-100 cm alt., ascendente, geralmente cespitoso, basalmente lenhoso. Caules subtetrágonos, marrom-escuros a castanhos, esfoliantes, marginados, glabros ou levemente pubérulos nas margens, com muitos nós vegetativos. Bainha estipular 2 mm compr., glabra, com 1-3 setas desiguais, seta central 2-2,5mm compr., setas laterais $0,5-0,8 \mathrm{~mm}$ compr., glabras, coléteres intercalares presentes. Folhas pseudoverticiladas pela presença de braquiblastos nas axilas, sésseis; lâminas 12-42×0,5-2 mm, lineares, acuminadas no ápice atenuadas na base, semisuculentas, glabras, margens ligeiramente curvas, glabras; nervuras secundárias imersas no mesofilo. Ramos florais com um glomérulo terminal 12-19 mm diâm., globoso, subtendido por 4 brácteas foliáceas, geralmente reflexas. Flores subsésseis, pedicelos ca. 0,4-0,5 mm compr. Hipanto turbinado, glabro. Cálice com pares de lobos fortemente desiguais, os maiores 1,2-1,5 mm compr., 

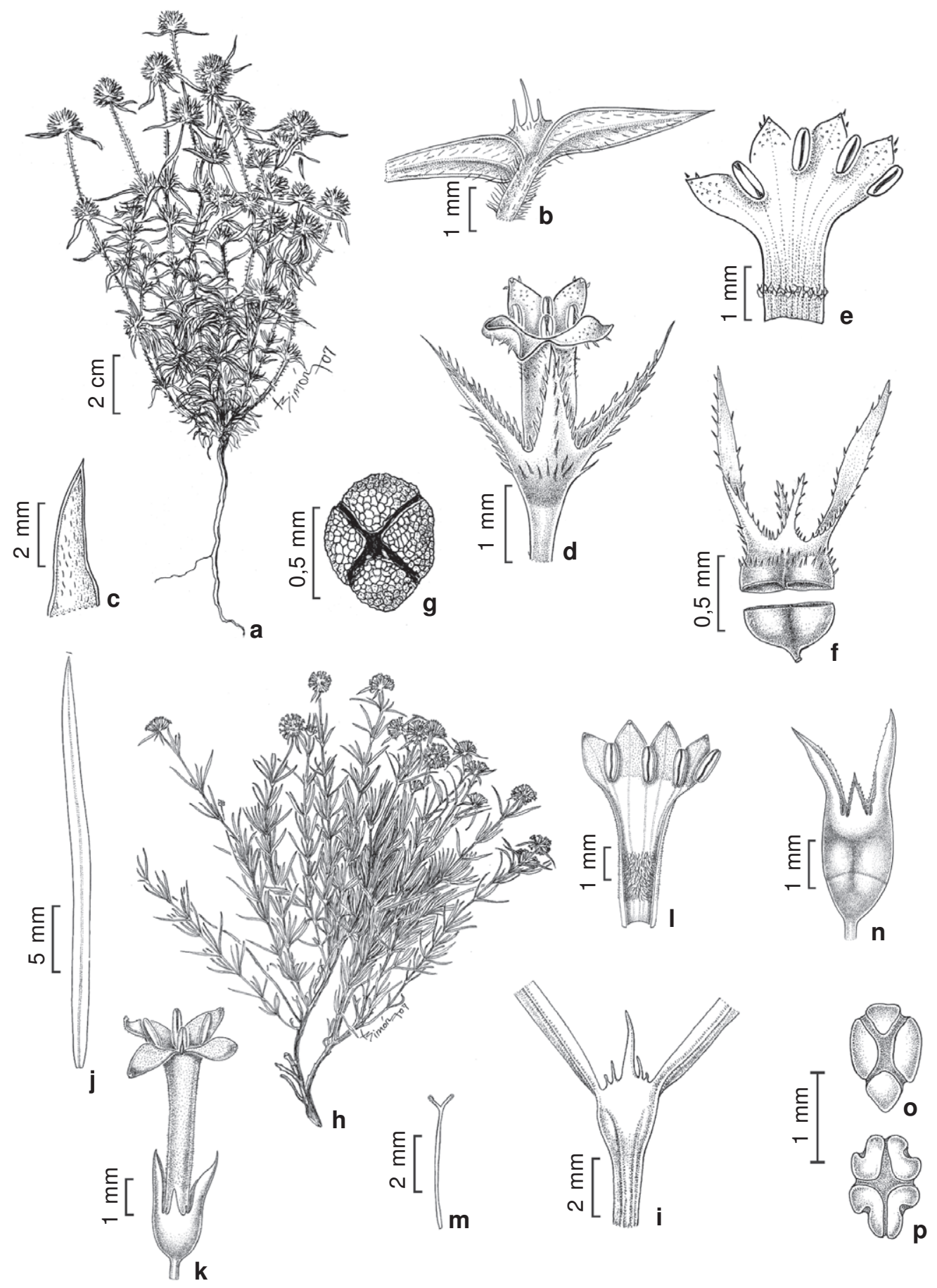

Figura 7 - a-g. Mitracarpus recurvatus - a. hábito; b. bainha estipular; c. folha; d. flor; e. corola aberta; f. cápsula aberta; g. semente, face ventral. h-p. M. rigidifolius - h. hábito; i. bainha estipular; j. folha; k. flor; 1. corola aberta; m. estilete; n. cápsula imatura; o. semente, face ventral; p. semente, face dorsal. (a Pereira 238; b-f Glaziou 21511; g Munhoz et al. 722; h França 2830; i-n Harley et al. 16651; o-p Ule 7559).

Figure 7 - a-g. Mitracarpus recurvatus - a. habit; b. stipular sheath; c. leaf; d. flower; e. open corolla; f. open fruit; g. seed, ventral view. h-p. M. rigidifolius - h. habit; i. stipular sheath; j. leaf; k. flower; 1. open corolla; m. style; n. young fruit; o. seed, ventral view; p. seed, dorsal view. (a Pereira 238; b-f Glaziou 21511; g Munhoz et al. 722; h França 2830; i-n Harley et al. 16651; o-p Ule 7559). 
lanceolados, escabros nas margens, os menores 0,6-1 mm compr., triangulares, escabros nas margens. Corola 5-6,5 mm compr., (sub)infundibuliforme; tubo 4-5 mm compr., densamente pubérulo-papiloso externamente, com faixa densa de tricomas moniliformes (1-1,6 mm compr) na região mediana interna; lobos 11,5 mm compr., ovados finamente pubérulos internamente. Estames subsésseis; filetes ca. $0,5 \mathrm{~mm}$ compr.; anteras 1-1,2×ca. 0,5 mm compr., subelípticas, subinclusas. Estilete 5-5,5 mm compr.; ramos estigmáticos ca. $0,5 \mathrm{~mm}$ compr. Cápsulas $2-2,5 \mathrm{~mm}$ compr., obcônicas, glabras; pedúnculo ca. $0,5 \mathrm{~mm}$ compr. Sementes $1-1,2 \times 0,6-0,8 \mathrm{~mm}$, obovóides, castanhos escuras a negras; face dorsal com depressão cruciforme impressa, exotesta retículo-foveolada; face ventral com encaixe em forma de "X"; prolongamentos do encaixe ventral evidentes nos ângulo da face dorsal. Material selecionado: BRASIL. BAHIA: Gentio do Ouro, $11^{\circ} 16^{\prime}$ 'S, $42^{\circ} 41^{\prime} \mathrm{W}, 30$.VI.1983, fl., L. Coradin et al. 6304 (K); 11'07'S, 4244'W, 24.II.1977, fl., R.M. Harley et al. 19042 (K, G). Morro do Chapéu, 11³6'04”'S,

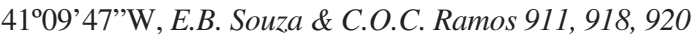

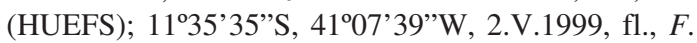
França 2830 (CEN, HUEFS). Umburanas: 10²0'S, 41ㅇ'ㄴ, 8.III.1974, fl., R.M. Harley et al. 17015 (K). Xique-Xique: $11^{\circ} 06$ 'S, $42^{\circ} 43^{\prime}$ W, 24 .VI.1996, fl. e fr., $P C D$ 3029 (HBR).

Mitracarpus rigidifolius é reconhecido por seu porte subarbustivo, cespitoso, folhas pseudoverticiladas, lineares, semisuculentas, glabras, glomérulos terminais globosos, corola com uma faixa densa de tricomas na região mediana interna, e sementes com depressão cruciforme na face dorsal. As características do porte, da bainha estipular, das folhas, das inflorescências, da carola, dos frutos e sementes relacionam esta espécie com M. bicrucis Bacigalupo \& E.L. Cabral, uma espécie reportada para a Bolívia (Bacigalupo \& Cabral 2005). Entretanto, $M$. rigidifolius é distinguível de $M$. bicrucis por ter folhas pseudoverticiladas (vs. folhas opostas) e glomérulo terminal subtendido por 4 brácteas foliáceas ( $v s$. glomérulo terminal subtendido por 8 brácteas foliáceas). Espécie endêmica do estado da Bahia, ocorrendo nos municípios de Morro do Chapéu, Umburanas, Xique-Xique e Gentio do Ouro, entre 500-1100 m de altitude. Habita áreas de solos arenosos profundos, entre afloramentos rochosos, tanto em vegetação de Campo Rupestre quanto em áreas de Cerrado. Quanto ao status de conservação, essa espécie é considerada como vulnerável [VU B2ab (iii)], por sua área de ocupação menor que 2.000 $\mathrm{km}^{2}$, com menos de 10 localidades conhecidas.
21. Mitracarpus robustus E.B. Souza \& E.L. Cabral, sp. nov. Tipo: BRASIL. CEARÁ: Mun. Porteiras, Chapada do Araripe, $07^{\circ} 28^{\prime} \mathrm{S}, 3^{\circ} 08^{\prime} \mathrm{W}, 930 \mathrm{~m}$, 30.III.2000, fl., P. Delprete, E.B. Souza, F.S. Cavalcanti \& L.W. Lima-Verde 7316 (holótipo EAC; isótipo HUEFS, NY). Fig. 8 a-g Mitracarpus frigidus var. humboldtianus sensu K. Schum. in Martius, Eichler \& Urban, Fl. bras. 6(6): 82. 1888. [Tab. 85], nom. illeg.

Haec species M. frigido similis, ab qua foliis oppositis (nec pseudoverticillatis), inflorescentiis cum 2-14 glomerulis per ramum floralem (vs. 1-3 in M. frigido), glomérulo terminali cum 2 bracteis involucralibus (nec 4 bracteis) et seminibus sine depressionibus dorsalibus differt.

Subarbusto 0,7-1,5(-2) $\mathrm{m}$ alt. Caules ascendentes, às vezes flexuosos, tetrágonos, fortemente alados nas porções basais, densamente pubérulos ou glabros. Bainha estipular 3-5 mm compr., coriácea, glabra, com 5-7 setas (3-)5-8(-10) mm compr., rígidas, canaliculadas ou estriadas, geralmente portando coléter apical. Folhas opostas sem braquiblastos nas axilas, geralmente pseudopecioladas; lâminas 20-90×3-28 mm, elípticas a estreito-elípticas, cartáceas, agudas a acuminadas no ápice, (longo-) atenuadas na base, pubérulas em ambas as faces, ou glabras na face superior, com denso arranjo de tricomas ao longo das nervuras na face inferior; nervuras secundárias 4-6 pares. Ramos florais com (2-)4-8(-14) glomérulos terminais e axilares; glomérulos 6-14 mm diâm., globosos, subtendidos por 2 brácteas foliáceas. Flores subsésseis, pedicelos ca. 0,5-0,7 mm compr. Hipanto turbinado, pubescente ou pubérulo. Cálice com pares de lobos desiguais, os maiores 1,5-2 mm compr., lanceolados, longamente acuminados, ciliados nas margens, verdes, os menores 1-1,5 m compr., estreito-triangulares, ciliados nas margens, sub-hialinos. Corola 3,5-4 mm compr., hipocrateriforme; tubo 2,5-3 mm compr., pubérulo na metade superior externa, com anel de tricomas moniliformes no terço inferior interno; lobos $0,8-1 \times 0,6-0,8 \mathrm{~mm}$, ovados, esparsamente pubérulos a pubérulo-papilosos, raramente glabros. Estames subsésseis; filetes ca. 0,5 mm compr.; anteras ca. 0,5-0,6 $\times 0,2-0,3 \mathrm{~mm}$, oblongas, subinclusas. Estilete filiforme 4-4,5 mm compr.; ramos estigmáticos ca. 0,5-1 mm compr. Cápsulas 1,5-2 ×0,8-1 mm compr., obcônicas, pubérulas na porção apical. Sementes ca. 0,8-1 ×0,5-0,6 mm, oblongóides ou obovóides, castanhas; face dorsal sem depressões, exotesta fovéolo-reticulada; face ventral com encaixe em forma de " $\mathrm{X}$ ". 
Material selecionado: BRASIL. BAHIA: Barra da

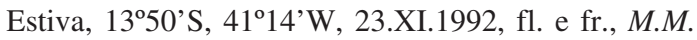
Arbo et al. 5722 (K, HUEFS). Morro do Chapéu,

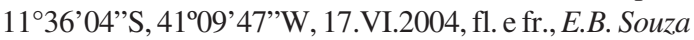
\& C.O.C. Ramos 919 (HUEFS). Mucugê, 1259'29”'S, 4120'33”'W, 10.VI.2004, fl. e fr., E.B. Souza et al. 895 (HUEFS). Salvador, $13^{\circ} 05^{\prime} 24^{\prime \prime} \mathrm{S}, 38^{\circ} 35^{\prime} 58^{\prime \prime} \mathrm{W}$, 28.X.1997, fl. e fr., G.A. Faria 92 (HBR). S. loc.: Cruz de Cosme, VII.1835, fl., B. Luschnath 93, 95 (BR); fl. e fr., J. Lhotzky s.n. (BM, G, K, P, W); 1831, fl. e fr., J. Blanchet $263(\mathrm{G}) ; 1832$, fl. e fr., J. Blanchet 166, (SP, G), 462 (G); 1834, fl., J. Blanchet s.n. (G); 1846 fl., J. Blanchet s.n. (G); IV.1831, J. Lhotzky s.n. (G); fl., G.H. Langsdorff 1057 (K, BM, W, G, P); fl., J. Lhotzky Fl. bras. Mart. 600 (K, BM, W, G, P). CEARÁ: Crato, $07^{\circ} 16^{\prime}$ 'S, $29^{\circ} 27^{\prime} \mathrm{W}$, 28.III.2000, fl., P. Delprete et al. 7297 (EAC, NY). Barbalha, $07^{\circ} 23^{\prime}$ 'S, $39^{\circ} 17^{\prime}$ W, 30.III.2000, fl., P. Delprete et al. 7313 (EAC, NY). DISTRITO FEDERAL: Brasília, 22.III.1978, fl., E.P. Heringer 18087 (RB). ESPÍRITO SANTO: Linhares, 15.VIII.1965, fl. e fr., A.P. Duarte 8876 (RB, UB). MINAS GERAIS: Belo Horizonte, Morro das Pedras, 30.VII.1945, fl. e fr., L.O. Williams \& V. Assis 8023 (BM, BR, G, K, R, RB, U). Juiz de Fora, Faz. Cachoeirinha, 17.VI.1946, fl. e fr., L. Roth 1716 (RB). Ouro Preto, 19.II.2002, fl., V.C. Souza et al. 28029 (HUEFS). Viçosa, Agricultural College lands, 19.V.1930, fl., Y. Mexia 4717 (K, BM, U, G). Sem indicação de localidade: 1816, fl., A. St.-Hilaire 2306 (P); fl. e fr., St.Hilaire 277 (P); fl. e fr., P. Claussen 157 (G, P); fl. e fr., $P$. Claussen 287a (BR); fl. e fr., P. Claussen 289a (BR); 1840, fl. e fr., P. Claussen 608 (BR). PARAÍBA: Areia, Escola de Agronomia do Nordeste, 30.X.1944, fl. e fr., J.M. Vasconcelos 349 (RB). S. loc.: 4.VI.1959, fl., J.C. Moraes 2144 (U). PERNAMBUCO: Caruaru, Distr. Murici, 6.IX.1995, fl. e fr., A.B. Marcon 68 (PEUFR). Recife, Dois Irmãos, fl. e fr., E.B. Souza 28 (PEUFR). RIO DE JANEIRO: Petrópolis, Vale Bom Sucesso, 13.IV.1968, fl., D. Sucre \& P.I.S. Braga 27577 (HUEFS). RIO GRANDE DO NORTE: Natal, Dunas de Mãe Luíza, 11.IX.1953, fl. e fr., S. Tavares 346 (HST). Nísia Floresta, Pirangi do Sul, Riacho do Cinzeiro, 8.IX.1953, fl. e fr., $S$. Tavares 296 (HST). SERGIPE: Areia Branca, Estação Ecológica da Serra de Itabaiana, 16.IX.1995, fl., M. Landim et al. 682 (HUEFS, UB). TOCANTINS: "in provincia Goyaz ad Porto Real" [atualmente mun. Porto Nacional], fl., W. J. Burchell 8713 (BR, P).

Mitracarpus humboldtianus é um nome supérfluo para M. frigidus. Chamisso \& Schlechtendal (1828) propuseram um novo epíteto por considerarem o anterior pouco conveniente, justificativa não aceita pelo Código Internacional de Nomenclatura Botânica (Art. 51.1 e Art. 56.1). Sendo $M$. humboldtianus um nome ilegítimo, $M$. frigidus var. humboldtianus também o é (Art. 11.4, CINB), mas o táxon ilustrado na Flora brasiliensis (Schumann 1888, tab. 85) merece reconhecimento, pois não corresponde ao tipo de $M$. frigidus. Esta nova espécie é aqui publicada como $M$. robustus. A presença de caules geralmente alados na base, a forma das folhas e a ausência de braquiblastos relaciona esta espécie com $M$. brasiliensis, uma espécie da região sul do Brasil (Porto et al. 1977). A análise dos caracteres polínicos e da escultura das sementes também ajuda a suportar esta estreita afinidade, pois ambas as espécies compartilham sementes com o mesmo tipo de escultura, além de grãos de pólen reticulados. Entretanto, M. robustus se diferencia de $M$. brasiliensis por apresentar porte mais robusto com 70-200 cm altura (vs. 30-45 cm altura), glomérulo apical subtendido por 2 brácteas (vs. 4 brácteas em M. brasiliensis), lobos menores do cálice estreitamente triangulares ( $v s$. filiformes em $M$. brasiliensis) e corola superando os maiores lobos do cálice ( $v s$. corola menor do que os maiores lobos do cálice em $M$. brasiliensis). Espécie com distribuição geográfica no Brasil e na Guiana Francesa. No Brasil, sua ocorrência está registrada para o Distrito Federal e para os estados do Ceará, Rio Grande do Norte, Paraíba, Pernambuco, Sergipe, Bahia, Minas Gerais, Espírito Santo e Rio de Janeiro. Planta comum em solos argilosos ou arenoargilosos, em solos lateríticos, em margens de estrada ou periferia de matas. Encontrada de 40$1350 \mathrm{~m}$ de altitude. Quanto ao status de conservação essa espécie é considerada como não ameaçada [NE].

22. Mitracarpus salzmannianus DC., Prodr. 4: 571. 1830. Mitracarpus frigidus var. salzmannianus (DC.) in Martius, Eichler \& Urban, Fl. bras. 6(6): 82. 1888. Tipo: BRASIL. s.l., 1827-1830, fl. e fr., P. Salzmann s.n. (holótipo G!; isótipo K!).

Fig. 8 h-o M. rudis Benth., Hooker's J. Bot. Kew Gard. Misc. 3:238. 1841. Tipo: GUIANA. 1837, R. Schomburgk 409 (holótipo K!; isótipo G!, W!), syn. nov.

Mitracarpus scabrellus Benth., Hooker's J. Bot. Kew Gard. Misc. 3: 238. 1841. Tipo: BRASIL. Rio Branco [agora estado de Roraima], 1840, $R$. Schomburgk 856 pro parte (holótipo B †; lectótipo $\mathrm{K}$ !, aqui designado; isolectótipo US), syn. nov.

Mitracarpus discolor Miq., Linnaea 18: 616. 1845. Mitracarpus frigidus var. discolor (Miq.) K. Schum., in Martius, Eichler \& Urban, Fl. bras. 6(6): 82. 1888. Tipo: SURINAME. "in savanis ad Onoribo", s.d., F.W.R. Hostmann 299 (holótipo U!; isótipo G!), syn. nov.

Erva ou subarbusto, ereto, ascendente ou decumbente (10-)25-100 cm alt. Caules tetrágonos, 


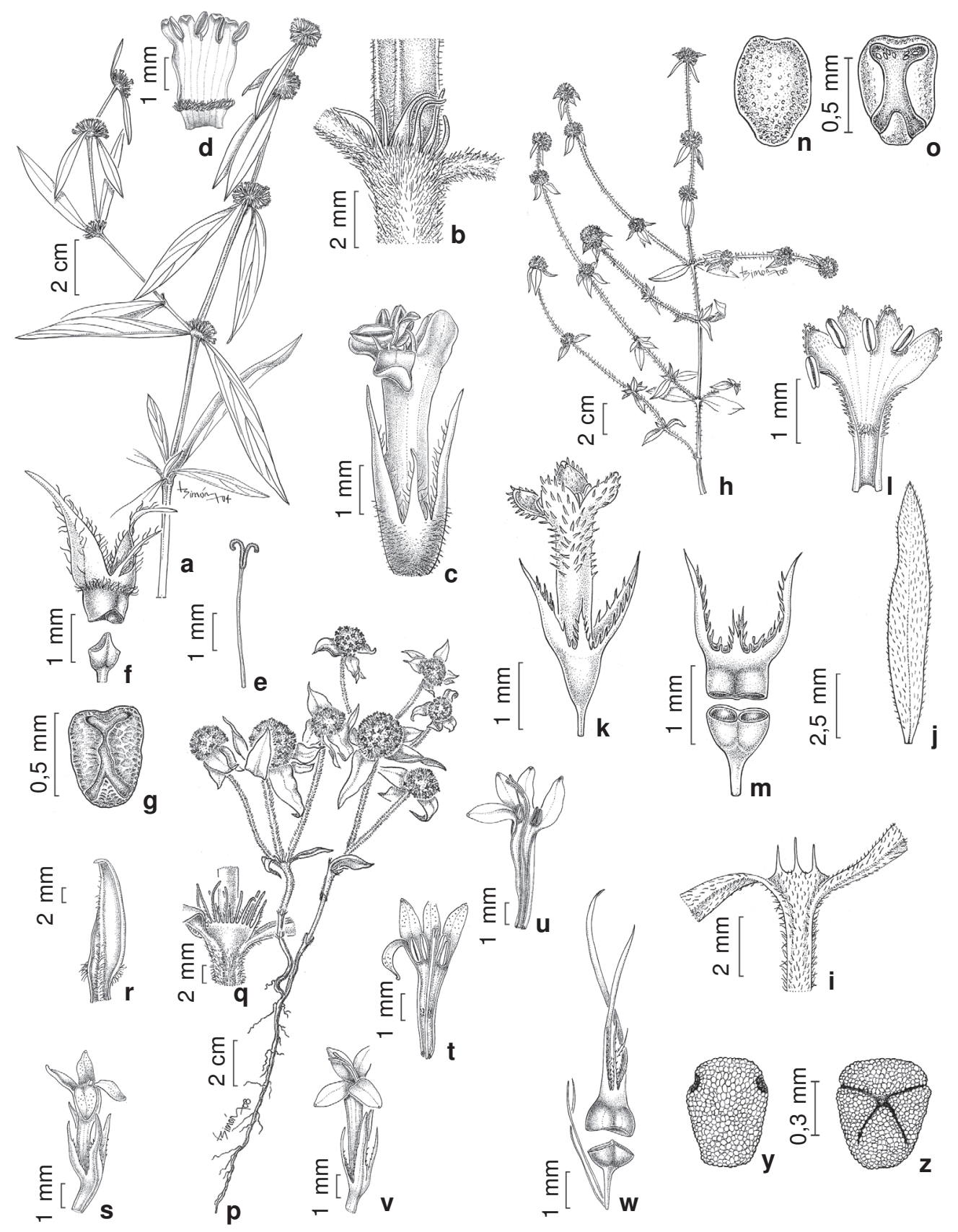

Figura 8 - a-g. Mitracarpus robustus - a. hábito; b. bainha estipular; c. flor; d. corola aberta; e. estilete; f. cápsula aberta; g. semente, face ventral. h-o. M. salzmannianus - h. ramo floral; i. bainha estipular; j. folha; k. flor; 1. corola aberta; m. cápsula aberta; n. semente, face dorsal; o. semente, face ventral. p-z. M. steyermarkii - p. hábito; q. bainha estipular; r. folha; s. flor, fase estaminada; t. flor aberta, fase estaminada; u. flor aberta, fase pistilada; v. flor, fase pistilada; w. cápsula aberta; y. semente, face dorsal; z. semente, face ventral. (a-g Duarte 8876; h Souza 965; i-o Schomburgk. 856 pro parte; p-w Proença et al. 2522; y-z Orlandi 95).

Figure 8 - a-g. Mitracarpus robustus - a. habit; b. stipular sheath; c. flower; d. open corolla; e. style; f. open fruit; g. seed, ventral view. h-o. M. salzmannianus - h. flowering branch; i. stipular sheath; j. leaf; k. flower; l. open corolla; m. open fruit; $n$. seed, dorsal view; o. seed, ventral view. p-z. M. steyermarkii - p. habit; q. stipular sheath; r. leaf; s. flower, staminate phase; t. open flower, staminate phase; u. open flower, pistilate phase; v. flower, pistilate phase; w. open fruit; y. seed, dorsal view; z. seed, ventral view. (a-g Duarte 8876; h Souza 965; i-o Schomburgk. 856 pro parte; p-w Proença et al. 2522; y-z Orlandi 95). 
escabros ou híspidos nas margens, escabros nas faces, raramente glabros nos entrenós, tricomas menores antrorsos. Bainha estipular 1-2 mm compr., pubescente, com (3-)7-11 setas 1-5 mm compr. filiformes, glabras. Folhas pseudoverticiladas pela presença de braquiblastos nas axilas, sésseis, discolores; lâminas (10-)20-35(-70) ×2-15(-30) mm, elípticas, estreitamente elípticas ou lineares, agudomucronadas no ápice, atenuadas na base, cartáceas, escabras em ambas as faces, ou densamente estrigosas na face superior, pubescentes ou estrigosas na face inferior, margens escabras, nervuras secundárias 2-3 pares, ou inconspícuas. Ramos florais com (1-) 2-4(-8) glomérulos terminais e axilares; glomérulos 5-21 mm diâm., globosos, subtendidos por 2-4 brácteas foliáceas. Flores pediceladas, pedicelos ca. 0,4-0,5 mm compr. Hipanto turbinado, glabro. Cálice com pares de lobos desiguais, os maiores 1,2-3,5 mm compr., lanceolados, aristados, ciliados, os menores (1-)1,2-2 compr., estreitamente-triangulares, hialinos, ciliados nas margens. Corola (3-)4,5-5,2 mm compr., hipocrateriforme; tubo (2,5-)3-4 mm compr., pubérulo-papiloso na metade superior externa, com anel de tricomas moniliformes inserido na região mediana interna; lobos (0,5-)1-1,2 mm compr., ovados, pubérulo-papilosos externamente. Estames sésseis, inseridos na fauce da corola; anteras ca. 0,5-0,8 $\times 0,4 \mathrm{~mm}$ compr., oblongas, subinclusas. Estilete (3-)4-5 mm compr., filiforme; ramos estigmáticos ca. $0,5 \mathrm{~mm}$ compr. Cápsulas (1,2-)1,52,5 mm compr., obovóides, glabras; pedúnculo $(0,5-)$ $1-1,5 \mathrm{~mm}$ compr. Sementes $0,8-1,2 \times 0,5-0,6 \mathrm{~mm}$, oblongóides ou globosas, castanhas; face dorsal sem depressões, exotesta fovéolo-reticulada; face ventral com encaixe em forma de "Y-invertido".

Material selecionado: BRASIL. ALAGOAS: Piaçabuçu, Cruiri Seco, 24.IX.1987, fl. e fr., M.N.R. Staviski et al. 1039 (SPF). BAHIA: Feira de Santana, 12²7'35"S, 41ํ2'25''W, 11.IX.2004, fl., E.B. Souza 965 (HUEFS). CEARÁ: Fortaleza, Campus do Pici, 4.VI.1993, fl. e fr., E.B. Souza \& A.R.M. Silveira s.n. (EAC 20236). ESPÍRITO SANTO: Presidente Kennedy, Praia das Neves, 6 km N da divisa com o RJ, 12.V.1983, fl. e fr., D. Araújo 5610 (UB). MARANHÃO: Carolina, $07^{\circ} 20^{\prime}$ 'S, $47^{\circ} 28^{\prime} \mathrm{W}, 1828$ 1830, fl. e fr., W.J. Burchell 9033 (K). PIAUÍ: Parnaíba Ilha de Santa Izabel, 4.X.1973, fl., D. Araújo et al. 459

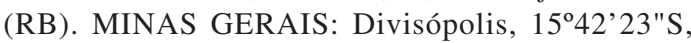
4001'35"W, 6.II.2002, fl. e fr., J.R. Pirani et al. 4987 (K). PARÁ: Oriximiná, Rio Trombetas, 13.VII.1980, fl. e fr., C.A. Cid et al. 1490 (RB). Santarém, III.1850, fl., R. Spruce 665 (BM, P). PARAÍBA: Mamanguape, Capim Azul, Estação Ecológica, 18.VIII.1988, fl. e fr., L.P. Félix \& C.A.B.Miranda 31 (JPB). PERNAMBUCO: Ipojuca, Serrambi, 29.V.1996, fl. e fr., E.B. Souza 111, 112 (PEUFR). RIO DE JANEIRO: Rio de Janeiro, 2300'13"S,
43²0'49”'W, 4.IV.1952, fl., L.B. Smith 6358 (BR). RIO GRANDE DO NORTE: Pendências, $15^{\circ} 36^{\prime}$ 'S, $43^{\circ} 20^{\prime} \mathrm{W}$, 10.IV.2002, fl., D.L. Santana \& L.A. Paraguassu 624 (ALCB). RORAIMA: Boa Vista, Rio Branco, fl., J.G. Kuhlmann 867 (RB). SERGIPE: Indiaroba, Pontal, 19.VIII.1995, fl., G. Hatschbach et al. 63222 (MBM).

Mitracarpus salzmannianus apresenta ampla variação morfológica ao longo de sua faixa de distribuição, principalmente no que se refere aos caracteres vegetativos. $O$ porte varia desde ervas eretas até subarbustos ascendentes ou decumbentes, de $10-100 \mathrm{~cm}$ altura, com folhas variando em tamanho e forma e densidade do indumento. Os caracteres florais e das sementes, contudo, são mais conservativos, o que indica haver um contínuo entre todos os morfotipos examinados. Estas observações levaram à sinonimização de $M$. discolor, $M$. scabrellus e $M$. rudis como variações morfológicas inseridas ao longo do faixa de distribuição de M. salzmannianus. Em razão da semelhança do porte, do caule e das folhas de alguns morfotipos, esta espécie é muito confundida com $M$. frigidus. Contudo, $M$. salzmannianus é distinguível por apresentar 1-8 glomérulos por ramo floral ( $v s .1-3$ glomérulos por ramo floral em M. frigidus), lobos maiores do cálice 1,2-3,5 mm compr. (vs. 3-5 mm compr.), encaixe ventral das sementes em forma de "Y-invertido" ( $v s$. em forma de " $\mathrm{X}$ ') e face dorsal das sementes sem depressões (vs. face dorsal das sementes com depressão cruciforme). M. salzmannianus apresenta estreita afinidade com $M$. eichleri, espécie típica do litoral brasileiro entre o Rio Grande do Norte e o Rio de Janeiro, com a qual compartilha os lobos maiores do cálice aristados e o mesmo tipo de encaixe ventral e escultura das sementes. Considerando que o material original consultado por Schumann foi destruído em Berlim (Stafleu \& Cowan 1976) e de acordo com indicações de Steyermark (1972), a parte da coleção Schomburgk 856 pro parte, depositada nos herbários de Ke US, foi escolhida como lectótipo de M. scabrellus Benth. Estes espécimes possuem o tubo da corola menor do que os maiores lobos do cálice. A outra parte da mesma coleção, depositada no herbário BM, com tubo da corola menor ou aproximadamente do mesmo comprimento que os maiores lobos do cálice, é o tipo de $M$. microspermus K. Schum. Mitracarpus salzmannianus é uma espécie amplamente distribuída, ocorrendo na Guiana, Suriname, Guiana Francesa e Brasil. No Brasil, sua ocorrência é registrada para os estados de Roraima, Pará, Maranhão, Piauí, Ceará, Rio Grande do Norte, Paraíba, Pernambuco, Alagoas, Sergipe, Bahia, Goiás, Minas Gerais, Espírito Santo e Rio de Janeiro. Espécie 
heliófita, encontrada desde o nível do mar até $930 \mathrm{~m}$ de altitude, em ambientes de savana, restingas, tabuleiros costeiros e campos rupestres. Planta comum em solos arenosos, habitando dunas, campos ou chapadas; também presente como ruderal em áreas de cultivo, nas capoeiras e beira de caminhos. Quanto ao status de conservação essa espécie é considerada como não ameaçada [NE].

23. Mitracarpus schininianus E.L. Cabral, Medina \& E.B. Souza, Candollea 64: 154. 2009. Mitracarpus frigidus K. Schum. var. glaberrimus Chodat \& Hassl. Bull. Herb. Boissier ser. 2, 4: 191. 1904. Tipo: PARAGUAI. CANINDEYÚ: Iter ad Yerbales, montium Sierra de Maracayú, s.d., fl. e fr., E. Hassler 5027 (lectótipo G!).

Subarbusto ereto ou apoiante $30-60(-80) \mathrm{cm}$ alt. Caules cilíndricos a obscuramente tetrágonos, glabros, com entrenós longos 4-8 cm compr. Bainha estipular 3-5 cm compr., subcoriácea, glabra, com 3 setas 1,3-2 mm compr. Folhas opostas, sem braquiblastos nas axilas, pseudopecioladas; lâminas 40-60×8-16 mm, elípticas, agudas no ápice, atenudas na base, cartáceas, margens glabras, glabras em ambas as faces; nervuras secundárias 2-3 pares, ou inconspícuas. Ramos florais com 2-4(-5) glomérulos terminais e axilares; glomérulos 10-20 mm diâm., subtendidos por 2-4 brácteas involucrais, foliáceas. Flores pediceladas, pedicelos ca. $1 \mathrm{~mm}$ compr. Hipanto obcônico, glabro. Cálice com lobos desiguais, os maiores triangulares, agudos, com margens irregulares, ciliadas, 2-2,5 mm compr., os menores estreitotriangulares, acuminados, com margens irregulares, ciliadas, 1-1,4 mm compr. Corola 3,5-5 mm compr., (sub)infundibuliforme; tubo 2-3,5 mm compr., com tricomas curtos no terço superior externo, com anel de tricomas moniliformes no terço inferior interno; lobos ca. $1 \mathrm{~mm}$ compr., triangulares, densamente papilados. Estames subsésseis, filetes ca. 0,6 mm compr., anteras ca. 0,8-1 $\times 0,5 \mathrm{~mm}$ compr, subinclusas. Estilete 6,5-7 mm compr., filiforme; ramos estigmáticos ca. $1 \mathrm{~mm}$ compr., densamente papilosos. Cápsulas 1,8$2 \times 1,5-1,7 \mathrm{~mm}$, subglobosas, glabras. Sementes 0,8$1,2 \times 0,9 \mathrm{~mm}$, oblongóides; face dorsal com depressão cruciforme impressa, exotesta fovéolo-reticulada; face ventral com encaixe em forma de " $X$ ".

Material selecionado: BRASIL. MATO GROSSO: Xavantina, Serra Azul, 15.VI.1966, fl. e fr., H.S. Irwin et al. 17170 (K, NY, UB). MATO GROSSO DO SUL: Três Lagoas, 2047'00"S, 5141'00"'W, 22.V.1964, fl. e fr., J.C. Gomes-Jr. 1781 (HUEFS, UB). TOCANTINS: Chapada das Mangabeiras, $09^{\circ} 93^{\prime} \mathrm{S}, 47^{\circ} 22^{\prime} \mathrm{W}$, 20.III.1978, fl., W.N. Fonseca 187 (HBR, RB).
Mitracarpus schininianus se caracteriza por seus caules alongados partindo da base, geralmente sem ramificações, bainha estipular subcoriácea, glabra, com 3 setas glabras, folhas opostas, pseudopecioladas, elípticas, cartáceas, glabras, lobos do cálice com margens irregulares, corola (sub)infundibuliforme e sementes com depressão cruciforme na face dorsal. Os caracteres das sementes de $M$. schininianus relacionam esta espécie a $M$. frigidus, pois ambas compartilham sementes com depressão cruciforme dorsal e padrão similar de escultura. Contudo, a primeira distingue-se por apresentar bainha estipular com 3 setas (vs. 4-12 setas em $M$. frigidus), folhas sem braquiblastos ( $v s$. folhas pseudoverticiladas pela presença de braquiblastos) e corola (sub)infundibuliforme ( $v s$. corola hipocrateriforme). Espécie com distribuição geográfica no Nordeste do Paraguai (Amambay, Canindeyú e San Pedro) (Cabral et al. 2009). Aqui é pela primeira vez citada para o Brasil, compreendendo os estados de Tocantins, Mato Grosso e Mato Grosso do Sul. Habita os campos cerrados, em solos arenosos ou rochosos. Quanto ao status de conservação essa espécie é considerada como não ameaçada [NE].

24. Mitracarpus steyermarkii E.L. Cabral \& Bacigalupo, Acta Bot. Bras. 11(1): 50. 1997. Tipo: BRASIL. BAHIA: Barreiras, $7 \mathrm{~km}$ S of Rio Piau, ca. $150 \mathrm{~km}$ SW of Barreiras, $850 \mathrm{~m}$, 13.IV.1966, fl., H.S. Irwin et al. 14690 (holótipo K!). $\quad$ Fig. 8 p-z Erva ereta (3-)5-10(-18) cm alt. Caules solitários ou com 2-3 ramificações laterais, entrenós fortemente encurtados, subtetrágonos, densamente híspidos. Bainha estipular 2-5 mm compr., glabra, com (5-)9-11 (-19) setas, 3-6 mm compr., glabras ou esparsamente barbeladas, ligeiramente encobertas pela base foliar. Folhas opostas, sésseis; lâminas 15-35 × 4-10 mm, ovadas, lanceoladas a linear-lanceoladas, agudas ou acuminadas no ápice, atenuadas na base, (sub)coriáceas, rígidas, glabras em ambas as faces ou somente com pubescência ao longo da nervura principal na face inferior, as margens fortemente espessadas, glabras na maior extensão, basalmente pubescentes; nervuras secundárias inconspícuas. Ramos florais com glomérulos solitários ou raramente com glomérulo subterminal, 13-21 mm diâm., semi-globosos, densifloros, subtendidos por 6-8 brácteas involucrais, foliáceas. Flores pediceladas, pedicelos $0,3-0,5 \mathrm{~mm}$ compr. Hipanto obcônico, glabro. Cálice com pares de lobos subiguais, os maiores, 3-5,5 mm compr., linear-lanceolados, carenados, escabros, os menores 2,5-4,5 mm compr., linear-lanceolados, escabros nas 
margens. Corola 5-7 mm compr., hipocrateriforme; tubo 3,5-5 mm compr., externamente glabro, com anel de tricomas moniliformes na porção mediana interna; lobos 1,5-2 mm compr., ovados, levemente papilosos na superfície interna. Estames sésseis, inseridos no tubo da corola; anteras 0,8-1 $\times 0,4-0,5 \mathrm{~mm}$., oblongas, inclusas. Estilete 5-6 mm compr., filiforme; ramos estigmáticos ca. 1 mm compr. Cápsulas 1,4-1,8 mm compr., obovóides, glabras, com tubo do cálice expandido até $1,2 \mathrm{~mm}$ compr. Sementes $0,6-0,8 \times$ ca. $0,5 \mathrm{~mm}$, obovóides, castanhas a castanho-claras; face dorsal sem depressão, exotesta papilada; face ventral com encaixe em forma " $X$ ".

Material selecionado. BRASIL. BAHIA: Barreiras, 13.IV.1966, fl., H.S. Irwin et al. 14690 (K). GOIÁS: Posse, 1403'59'S, 46¹7'03”'W, 14.IV.2005, fl. e fr., E.B. Souza et al. 1171, 1173 (HUEFS). MINAS GERAIS: Januária, 18.IV.1973, fl. e fr., W.R. Anderson 9019 (UB, NY). TOCANTINS: Mateiros, $10^{\circ} 33$ 'S, 460'ㄴ, 8.V.2001, fl., C. Proença et al. 2522 (UB). Serra do Jalapão, 10¹4'S, 4657'W, 27.IV.1978, fl. e fr., R.P. Orlandi 95 (HBR).

Mitracarpus steyermarkii é uma espécie distinguível por seu porte reduzido, ereto, com caule solitário ou pouco ramificado, com escassos nós vegetativos, folhas (linear-) lanceoladas fortemente (sub)coriáceo-rígidas, glomérulos terminais globosos, densifloros, lobos do cálice subiguais, estames inclusos no tubo da corola e sementes papiladas. Mitracarpus steyermarkii tem afinidade com $M$. recurvatus e $M$. pusillus, espécies endêmicas ou com distribuição restrita no cerrado e no campo rupestre, respectivamente. Estas três espécies compartilham folhas rígidas, e sementes com exotesta papilada. Espécie com distribuição geográfica restrita às áreas de cerrado arenoso do sudeste de Tocantins, oeste da Bahia, leste de Goiás e noroeste de Minas Gerais. Quanto ao status de conservação, essa espécie é considerada como vulnerável [VU B2ab(iii)]. A área de ocupação é menor do que $2.000 \mathrm{~km}^{2}$, com menos de 10 localidades conhecidas. Nenhuma de suas populações encontra-se dentro de áreas protegidas e o crescente avanço mecanizado das fronteiras agrícolas ameaça o seu habitat natural.

\section{Nomes excluídos}

Mitracarpus filipes Huber, Bull. Herb. Boissier 2(1): 326. 1901. Holótipo: J. Huber 63 (G!). Isótipo deste material encontrado no Herbário RB(!). Trata-se de um espécime de Staelia.

Mitracarpus flagellatus Sucre, Loefgrenia 38: 2. 1969. Holótipo: J.M. Pires \& G.A. Black 2546 (IAN!). A análise da morfologia floral, com estames inseridos na base do tubo da corola e estilete curto, apenas superando o disco nectarífero, indica se tratar de um espécime de Borreria seção Pseudodiodia.

Mitracarpus rizzinianus Machado, Publ. Minist. Agric. Cons. Nac. Prot. Ind. Hist. Nat. 103(5): 47. 1954. Holótipo: O. Machado 236 (RB!). A análise da morfologia floral e dos frutos indicou tratar-se de um espécime de Staelia virgata (Willd. ex Roem. \& Schult.) K. Schum., conforme foi constatado por Sucre \& Costa (1970) a partir da análise do padrão de venação foliar e dos demais caracteres morfológicos.

\section{Agradecimentos}

À Carlianne O.C. Ramos, a colaboração no trabalho de campo; a Roberto Salas, a ajuda com a elaboração de desenhos e digitalização das imagens; aos assessores anônimos pelas críticas e sugestões; aos curadores dos Herbários visitados, todo o apoio e colaboração prestados ao trabalho; ao Prof. Cássio van den Berg, a composição das diagnoses latinas; aos professores Alessandro Rapini, Flávio França, Cláudia Elena Carneiro e Maria Regina de Vasconcelos Barbosa, as críticas e sugestões na elaboração dos artigos; ao Prof. Piero Delprete, as sugestões e literaturas enviadas; aos colegas do Royal Botanic Gardens, Kew, o apoio e contribuição prestados; ao programa KLARF (Kew Latin American Research Fellowships Programme), a bolsa que propiciou o estágio em Kew e a visita aos herbários europeus, e à Fundação Cearense de Apoio ao Desenvolvimento Científico e Tecnológico (FUNCAP) a bolsa de doutorado do primeiro autor, que permitiu o desenvolvimento da pesquisa.

\section{Referência}

Andersson, L. 1992. A provisional checklist of Neotropical Rubiaceae. Scripta Botanica Belgica 1: 1-230.

Bacigalupo, N.M. 1974. Rubiaceae in Burkart, A. Flora ilustrada de Entre Rios. Vol. 6. INTA, Buenos Aires. Pp. 3-50.

Bacigalupo, N.M. 1993. Rubiaceae. In: Cabrera, A.L. Flora de la Provincia de Jujuy - Republica Argentina. Vol. 13. INTA, Buenos Aires. Part. 9. Pp. 375-437.

Bacigalupo, N.M. 1996. Flora del Vale de Lerma. Aportes Botanicos de Salta 4: 1-52.

Bacigalupo, N.M. \& E.L. Cabral. 2005. Borreria santacruciana y Mitrcarpus bicrucis (RubiaceaeSpermacoceae), nuevas especies de Bolivia. Darwiniana 43: 69-75.

Borhidi, A. \& Lozada, L. 2007. Estudios sobre Rubiáceas Mexicanas XII. El género Mitracarpus Zucc. ex 
Roem. et Schult. f. (Spermacoceae) en México. Acta Botanica Hungarica 49: 27-45.

Cabral, E.L.; Medina, W.A. \& Souza, E.B. 2009. Novedades en el género Mitracarpus (Spermacoceae - Rubiaceae) para la flora del Paraguay. Candollea 64: 152-156.

Cabral, E.L. \& Bacigalupo, N.M. 1997. Nuevas espécies de la tribu Spermacoceae (Rubiaceae) para la flora de Brasil. Acta Botanica Brasilica 11: 45-54.

Chamisso, L.A. von \& Schlechtendal, D.F.L. von. 1828. De plantis in expeditione speculatoria romanzoffiana observatis. Linnaea 3: 338-366.

Delprete, P.; Smith, L.B. \& Klein, R.M. 2005. Rubiáceas, Vol. 2. Gêneros de G-Z. In: Reis, A. Flora Ilustrada Catarinense. I Parte, Monografia RUBI. Herbário Barbosa Rodrigues, Itajaí. Pp. 345-843.

Dessein, S. 2003. Systematic studies in the Spermacoceae (Rubiaceae). K.U. Leuven, Institute of Botany and Microbiology. 403p.

Fosberg, F.R.; Sachet, M.-H \& Oliver, R.L. 1993. Rubiaceae. Flora of Micronesia. BignoniaceaeRubiaceae. Smithsonian Contribution Botany. Vol. 81. Part. 5. Pp. 44-135.

Holmgren, P.K.; Holmgren, N.H. \& Barnett, L.C. 1990. Index Herbariorum. Part. I: The herbaria of the world. Regnum vegetabile. $8^{\mathrm{a}}$ ed. New York Botanical Garden, New York. 693p.

IUCN 2001. IUCN Red List Categories. Prepared by the IUCN Species Survival Comission. IUCN, Gland, Switzerland and Cambridge, U.K.

Liogier, H.A. 1963. Tomo 5 - Rubiales, Valerianales, Cucurbitales, Campanulales, Asterales. Flora de Cuba. Universidad de Puerto Rico. Editorial Universitaria, Rio de Pedras.

Liogier, H.A. 1995. La flora de la Española. VII. Vol. LXXI. s.c. 28. San Pedro de Marcorís, R.D. Pp. 335-339.

Liogier, H.A. 1997. Descriptive flora of Puerto Rico and adjacent Islands. Vol. 5. Editorial de la Universidad de Puerto Rico. Pp. 121-125.

McNeill, J.M.; Barrie, F.R.; Burdet, H.M.; Demoulin, V.; Hawksworth, D.L.; Marhold, K.; Nicolson, D.H.; Prado, J.; Silva, P.C.; Skog, J.E. \& Wiersema, J.H. 2006. Código Internacional de Nomenclatura
Botânica (Código de Viena). Instituto de Botânica, São Paulo. 181p.

Nicolson, D.H. 1977. Typification of names vs. typification of taxa: proposals on article 48 and reconsideration of Mitracarpus hirtus vs. M. villosus (Rubiaceae). Taxon 26: 573.

Porto, M.L.; Jacques, S.M.C.; Miotto, S.T.S.; Waechter, J.L. \& Detoni, M.L. 1977. Flora ilustrada do Rio Grande do Sul: Tribo Spermacoceae. Boletim do Instituto Central de Biociências, Série Botânica 35: 1-114.

Schumann., K. 1888. Mitracarpus. In: Martius, C.F.P. von $\&$ auct. suc. (ed.). Flora brasiliensis. Vol. 6. P. 82.

Steyermark, J.A. 1972. The botany of the Guyana highland - Part 9. Memoirs of the New York Botanical Garden 23: 777-784.

Steyermark, J.A. 1974. In: Lasser, T. Flora da Venezuela. Instituto Botánico. Caracas. Vol. 9. Pp. 1838-1850.

Souza, E.B. \& Sales, M.F. 2001 [2002]. Mitracarpus longicalyx (Rubiaceae, Spermacoceae), a new species from northeastern Brazil. Brittonia 53: 482-486.

Stafleu, F.A. \& Cowan, R.S. 1976-1986. Taxonomic literature. Vols. 1-6. Utrecht: Bohn, Sheltema \& Holkema.

Sucre, D. \& Costa, C.G. 1970. Duas novas espécies da Tribo Spermacoceae e considerações sobre duas sinonímias. Loefgrenia 48: 1-14.

Terrell, E.E. \& Wunderlin, R.P. 2002. Seed and fruit characters in selected Spermacoceae and comparison with Hedyotideae (Rubiaceae). Sida 20: 549-557.

Urban, I. 1903, 1908, 1913, 1928. Mitracarpus In: Urban, I. (ed.). Symbolae antillanae seu fundamenta florae Indiae occidentalis. 9 vols. Berlin, Leipzig, Paris, London.

Velloso, A.L.; Sampaio, E.V.S.B.; Giulietti, A.M.; Barbosa, M.R.V.; Castro, A.A.J.F.; Queiroz, L.P.; Fernandes, A.; Oren, D.C.; Cestaro, L.A.; Castro, A.J.E.; Pareyn, F.G.C.; Silva, F.B.R.; Miranda, E.E.; Keel, S. \& Gondim, R.S. 2002. Ecorregiões propostas para o Bioma Caatinga. TNC-Brasil, Associação Plantas do Nordeste, Recife.

Verdcourt, B. 1975. Studies on the Rubiaceae - Rubioideae for the "Flora of Tropical Africa." Kew Bulletin 30: 247-326. 
Anexo - Índice dos taxa. Em negrito estão os binômios aceitos neste tratamento. Os números entre parêntesis se referem à ordem seguida no tratamento taxonômico.

Mitracarpus albomarginatus E.B. Souza (1)

M. anthospermoides K. Schum. (2)

M. baturitensis Sucre (3)

M. brasiliensis M.L. Porto \& Waechter (4)

M. buiquensis E.B. Souza \& Zappi (5)

M. cuspidatus DC. $=$ M. megapotamicus

M. diffusus (Willd. ex Roem. \& Schult.) Cham. \& Schltdl. $=M$. hirtus

M. discolor Miq. = M. salzmannianus

M. diversifolius E.B. Souza \& E.L. Cabral (6)

M. eichleri K. Schum. (7)

M. eitenii E.B. Souza \& E.L.Cabral (8)

M. eritrichoides Standl. (9)

M. felipponei Beauverd $=$ M. megapotamicus

M. filipes Huber $=$ Staelia $\mathrm{sp}$.

M. flagellatus Sucre = Borreria sp. (seção Pseudodiodia $)$

M. frigidus (Willd. ex Roem. \& Schult.) K. Schum. (10)

$M$. frigidus var. andinus Steyerm. $=M$. frigidus

M. frigidus var. discolor (Miq.) K. Schum. $=M$. salzmannianus

M. frigidus var. humboldtianus (Cham. \& Schltdl.) K. Schum. $=M$. robustus

M. frigidus var. salzmannianus (DC.) K. Schum. $=M$. salzmannianus

M. fruticosus Standl. = M. frigidus

M. frigidus var. fruticosus (Stand1.) Steyerm. $=$ M. frigidus

M. frigidus K. Schum. var. glaberrimus Chodat \& Hassl. = M. schininianus

M. frigidus var. orinocensis Steyerm. $=M$. frigidus

M. frigidus var. peruvianus Steyerm. $=M$. frigidus

M. hirtus (L.) DC. (11)

M. humboldtianus Cham. \& Schltdl. = M. frigidus

M. Ihotzkyanus Cham. (12)

M. longicalyx E.B. Souza \& M.F. Sales (13)

M. megapotamicus (Spreng.) O. Kuntze (14)
M. megapotamicus (Spreng.) Standl. (14)

M. microspermus K. Schum. (15)

M. minutiflorus K. Schum. = M. microspermus

M. microphyllus Glaziou $=M$. recurvatus

M. nitidus E.B. Souza \& Zappi (16)

M. parvulus K. Schum. (17)

M. peladilla Griseb. $=$ M. megapotamicus

M. pusillus Steyerm. (18)

M. recurvatus Standl. (19)

M. rigidifolius Standl. (20)

$M$. rizzinianus Machado = Staelia virgata

M. robustus E.B. Souza \& E.L. Cabral (21)

M. rudis Benth. $=$ M. salzmannianus

M. salzmannianus DC. (22)

M. scaber Zucc. ex Schult. \& Schult. f. = M. hirtus

M. scabrellus Benth. $=$ M. salzmannianus

M. schininianus E.L. Cabral, Medina \& E.B. Souza (23)

M. sellowianus Cham. \& Schltdl. = M. megapotamicus

M. selloanus var. latifolius f. latifolius Chodat \& Hassl. = M. megapotamicus

M. selloanus var. latifolius f. robustus Chodat \& Hassl. = M. megapotamicus

M. selloanus var. latifolius f. tenellus Chodat \& Hassl. $=M$. megapotamicus

M. sellowianus Cham. \& Schltdl. = M. megapotamicus

M. senegalensis DC. $=$ M. hirtus

M. steyermarkii E.L. Cabral \& Bacigalupo (24)

M. verticillatus (Schumach. \& Thonn.) Vatke $=M$. hirtus

M. villosus (Sw.) DC. $=M$. hirtus

Schizangium Bartl. ex DC. = Mitracarpus

Spermacoce diffusa Willd. ex Roem. \& Schult. = M. hirtus

S. frigida Willd. ex Roem. \& Schult. = M. frigidus

$S$. megapotamica Spreng. $=$ M. megapotamicus

Staurospermum Thonn. = Mitracarpus

S. verticillatum Schumach. \& Thonn., Beskr. $=M$. hirtus 